http://dx.doi.org/10.18778/1509-877X.2018.03.06

\title{
„USZCZELNIANIE SYSTEMU VAT” - PRÓBA OCENY SKUTECZNOŚCI PODJĘTEGO WYSIŁKU LEGISLACYJNEGO I ORGANIZACYJNEGO
}

Streszczenie. Artykuł koncentruje się na przebiegu działań legislacyjnych i organizacyjnych mających na celu zwiększenie wydajności fiskalnej podatku od towarów i usług, podejmowanych w szczególności po 2015 roku. Główne pytanie badawcze dotyczy realizacji celów postawionych przez inicjatorów procesu „uszczelniania podatku VAT” oraz kosztów tego procesu. Jako koszty procesu zostały wskazane koszty pozafiskalne ponoszone przez podatników, w postaci obciążeń administracyjnych. Celem opracowania jest próba odpowiedzi na pytanie badawcze poprzez przedstawienie genezy, obecnego stanu oraz próby oceny w kategorii koszt/efekt wprowadzonych zmian legislacyjnych i organizacyjnych.

Słowa kluczowe: podatek VAT, zamykanie luki podatkowej, koszty administracyjne

\section{WPROWADZENIE}

Jako jedną z podstawowych wad polskiego prawa podatkowego wskazuje się jego częstą zmienność legislacyjną. Jednak aktywność legislacyjna w obszarze podatku od towarów i usług w ostatnich kilku latach wykazuje niespotykane wcześniej cechy. Działania te charakteryzują się rzadko obecną w latach poprzednich spójnością i dążeniem do wyznaczonego celu. Jest nim zwiększenie wydajności fiskalnej podatku od towarów i usług, które

* Doktor, uczestnik seminarium naukowego $\mathrm{w}$ ramach forum prawa podatkowego, Zakład Prawa Finansowego i Podatkowego Akademii Leona Koźmińskiego, e-mail: marek.beldzikowski@gmail.com 
w debacie publicznej prezentowane jest pod uproszczonym określeniem „uszczelniania VAT-u”. Pod tym terminem kryje się wiele już obowiązujących i oczekujących na wprowadzenie rozwiązań, bardzo często wykraczających poza zakres legislacyjny ustawy o podatku od towarów i usług. Szczególne zainteresowanie ustawodawcy wydajnością fiskalną podatku od towarów i usług nie jest przypadkiem. Podatek od towarów i usług stanowi główne źródło przychodów budżetowych. VAT wpływa również w sposób istotny na podatek akcyzowy, który z definicji obciąża popularne i przynoszące duże marże towary. Uszczelnienie podatku VAT „przy okazji” powoduje wzrost wpływów z podatku akcyzowego. Zmiany rozmiaru szarej bądź czarnej strefy szybko znajdują odbicie we wzroście bądź spadku wpływów z podatku VAT. Znaczenie fiskalne podatku VAT z punktu widzenia Skarbu Państwa jest więc dużo większe niż formalnie rejestrowane wpływy $\mathrm{z}$ tego podatku.

2. Pierwsze projekty Legislacyjne o stricte „USZCZELNIAJĄCYM” CHARAKTERZE

Za historycznie pierwszą propozycję legislacyjną, której celem było właśnie zwiększenie wydajności fiskalnej podatku od towarów i usług, można uznać wprowadzenie, a następnie rozszerzanie zakresu tzw. odwrotnego obciążenia (ang. reverse charge).

Mechanizm odwrotnego obciążenia jest wyjątkiem od podstawowych reguł podatku od towarów i usług. Sprzedawca nie dokonuje obciążenia podatkiem należnym, choć zachowuje prawo do odliczenia podatku naliczonego dotyczącego tej sprzedaży, podatek należny nalicza zaś nabywca, niemniej kwotę tę odlicza jako podatek naliczony. W rezultacie do budżetu państwa nie wpływa podatek od wartości dodawanych na poszczególnych etapach obrotu, a efektywne obciążenie zostaje odroczone do etapu sprzedaży ostatecznemu konsumentowi lub podatnikowi, który nie stosuje już mechanizmu odwrotnego obciążenia. Zbliża to podatek VAT do podatku jednofazowego od sprzedaży detalicznej, co jest zasadniczym przedmiotem kontrowersji wokół odwróconego obciążenia. Tradycyjnie mechanizm odwróconego obciążenia stosuje się w transakcjach, które przebiegają na granicy różnych jurysdykcji, np. transakcje importu czy wewnątrzwspólnotowego nabycia towarów. W odniesieniu do takiego typu transakcji klasyczne mechanizmy podatku od wartości dodanej okazują się niewystarczające dla zabezpieczenia interesów fiskusa. Jeśli mechanizm naliczania 
i odliczania podatku VAT przekracza jurysdykcję państwa, zastosowanie mechanizmu odliczenia i/lub zwrotu podatku naliczonego z zagranicznych faz obrotu jest faktycznie niemożliwe. Co więcej, hipotetyczna egzekucja podatku, jeśli mamy do czynienia z nieuczciwie działającym podmiotem gospodarczym, jest iluzoryczna.

Przecięcie łańcucha transakcji, w których następuje przeniesienie podatku naliczonego, w przypadku dóbr sprowadzanych na terytorium kraju, zapewnia równą konkurencję względem krajowych wytwórców. Brak mechanizmu odwróconego obciążenia spowodowałby wyłączenie spod opodatkowania dóbr sprowadzonych z zagranicy, co naruszyłoby konkurencję względem krajowych wytwórców. Właśnie ta cecha, czyli usunięcie podatku naliczonego, było uzasadnieniem dla przeniesienia mechanizmu odwróconego obciążenia na grunt transakcji krajowych.

Zasadniczym celem wprowadzenia mechanizmu odwrotnego obciążenia było przeciwdziałanie oszustwom i nadużyciom, a w szczególności tzw. oszustwom karuzelowym. Choć to pojęcie nie jest pojęciem normatywnym, to funkcjonuje ono jako określenie jednego ze schematów transakcji służących uzyskaniu nienależnych korzyści poprzez wykorzystanie konstrukcji podatku od towarów i usług ${ }^{1}$. Mechanizm przestępczy tego typu bazuje na możliwości dokonywania wyłudzeń wynikających $\mathrm{z}$ nieuzasadnionego odliczenia i zwrotu - jako podatku naliczonego - kwot, które jedynie „podszywają się” pod niego w sfałszowanej dokumentacji. Klasyczna forma oszustwa karuzelowego polega na posłużeniu się fakturą nieodzwierciedlającą rzeczywistej transakcji gospodarczej, która rodziłaby na wcześniejszym etapie podatek należny, zadeklarowany i odprowadzony do urzędu skarbowego. Mechanizm odwrotnego obciążenia uniemożliwia użycie objętych nim dóbr do tego typu oszustwa, gdyż brakuje newralgicznego odliczenia przez nabywcę kwoty wykazanej na fakturze jako podatek. Rozumowanie to stało się uzasadnieniem rozszerzania tego mechanizmu na kolejne segmenty obrotu krajowego ${ }^{2}$.

Ustawa z dnia 11 marca 2004 r. o podatku od towarów i usług po raz pierwszy implementowała mechanizm odwrotnego obciążenia w obrocie

${ }^{1}$ A. Mudrecki, Wykorzystanie mechanizmu odliczenia podatku naliczonego $w$ systemie VAT do oszustw w postaci „karuzeli podatkowych”, „Krytyka Prawa” 2018, t. 10, nr 3, s. $262-277$.

${ }^{2}$ K. Radzikowski, Mechanizm odwrotnego obciążenia - sanacja czy destrukcja podatku od towarów i usług?, „Doradztwo Podatkowe - Biuletyn Instytutu Studiów Podatkowych" 2018, nr 5, s. 8. 
krajowym z dniem 1 kwietnia 2011 r. ${ }^{3}$ Mechanizm ten został wprowadzony do transakcji, których przedmiotem był obrót złomem oraz uprawnienia do emisji gazów cieplarnianych. $Z$ dniem 1 lipca 2011 r. wprowadzono załącznik nr 11 do ustawy o podatku od towarów i usług zawierający zamknięty katalog towarów objętych tym mechanizmem. Kolejne rozszerzenia zakresu tego załącznika miały miejsce w dniach 1 października 2013 r., 1 lipca 2015 r. i 1 stycznia 2017 r. - wtedy objęto nim także roboty budowlane wymienione w nowo wprowadzonym załączniku nr 14 do ustawy, pod warunkiem że świadczy je podwykonawca.

Czy cele stawiane przez ustawodawcę zostały zrealizowane? Wydaje się, że nawet w roku 2020 brak jednoznacznej oceny skuteczności mechanizmu reverse charge. W opinii projektodawcy kolejnych nowelizacji ustawy o podatku od towarów i usług ten mechanizm ogranicza wyłudzenia i nadużycia, co uzasadnia jego dalsze rozszerzanie ${ }^{4}$. Warto jednak podkreślić, że w dokumentach urzędowych zdarzają się niejednoznaczne oceny tego mechanizmu ${ }^{5}$. Co gorsza, w dyskusji prowadzonej przez praktyków i teoretyków prawa podatkowego dominują skrajne stanowiska. Z jednej strony podnosi się, że żadne wiarygodne dane statystyczne nie wykazały wzrostu dochodów budżetowych dzięki mechanizmowi, a wręcz przeciwnie - potwierdzają wzrost liczby deklaracji wykazujących zwrot podatku (czyli wzrost obciążeń administracyjnych) z pozostałymi tego faktu konsekwencjami. Z drugiej strony wskazywane są realne korzyści, które miałoby z punktu widzenia Skarbu Państwa generować objęcie tym rozwiązaniem niektórych sektorów, polegające głównie na wzroście wpływów budżetowych ${ }^{6}$. Wydaje się, że przynajmniej pierwszy okres stosowania odwrotnego

3 Tekst jedn. Dz.U. z 2017 r., poz. 1221 ze zm.

4 Zob. uzasadnienia kolejnych ustaw nowelizujących ustawę o podatku od towarów i usług, druki sejmowe: 1515/VII kadencja, 3077/VII kadencja i 965/VIII kadencja.

${ }^{5}$ Wyniki analiz oraz kontroli organów kontroli skarbowej i wywiadu skarbowego wskazały, że odwrotne obciążenie nie rozwiązuje problemu oszustw w sposób systemowy, ale jedynie doraźnie: „Nie można jednoznacznie stwierdzić, czy mechanizm ten przeciwdziała oszustwom podatkowym, czy też rozszerzenie jego zakresu zwiększa skalę wyłudzeń" (Przeciwdziałanie wprowadzaniu do obrotu gospodarczego faktur dokumentujących czynności fikcyjne. Informacja o wynikach kontroli NIK, KBF.410.007.00.2015, Nr ewid. 24/2016/P/15/011/KBF, Warszawa 2015, s. 24).

${ }^{6}$ Przykładem pozytywnej oceny odwróconego obciążenia jest opracowanie oceniające wprowadzenie od dnia 1 października 2013 r. odwróconego obciążenia VAT na niektóre wyroby stalowe - CASE (Warszawa 2015), które wskazuje na bezpośredni zysk Skarbu Państwa w wysokości 537 mln zł. 
obciążenia nie powodował takich skutków. Zmiany w tym zakresie obserwowane od 2017 r. należy wiązać z wieloma innymi środkami o charakterze „uszczelniającym”, a nie wyłącznie z mechanizmem odwróconego obciążenia.

Chronologicznie kolejnym rozwiązaniem o charakterze „uszczelniającym” wprowadzonym 1 października 2013 r. był mechanizm tzw. odpowiedzialności solidarnej ${ }^{7}$. Mechanizm ten polega na tym, że podatnik, na rzecz którego dokonano dostawy towarów, o których mowa była w załączniku nr 13 do ustawy o podatku od towarów i usług (lista tzw. towarów wrażliwych), odpowiadał solidarnie wraz z podmiotem dokonującym tej dostawy za jego zaległości podatkowe w części podatku proporcjonalnie przypadającej na dostawę dokonaną na rzecz tego podatnika. Powodowało to, że organ podatkowy mógł dochodzić zapłaty podatku od wybranego przez siebie podmiotu zobowiązanego solidarnie. Odpowiedzialność ta zostawała wyłączona, gdy zainteresowany złożył w urzędzie skarbowym kaucję gwarancyjną. Stanowiła ona zabezpieczenie zapłaty podatku wraz z odsetkami za zwłokę w związku z dokonywaniem dostaw tych towarów oraz powstałych po wniesieniu kaucji gwarancyjnej zaległości podatkowych w podatkach stanowiących dochód budżetu państwa. Wysokość kaucji gwarancyjnej podlegała istotnym modyfikacjom, np. 1 lipca 2015 r. podwyższono jej wysokość dla podmiotów dokonujących dostaw tzw. towarów wrażliwych z minimalnej 200 tys. zł do 1 mln zł i z maksymalnej $3 \mathrm{mln}$ zł do $10 \mathrm{mln}$ zł. Jednocześnie, w toku kolejnych nowelizacji, rozszerzano zakres transakcji, które podlegały solidarnej odpowiedzialności. W ostatecznej formie objęto nią dostawy niektórych wyrobów stalowych, paliw oraz złota nieobrobionego plastycznie lub w postaci półproduktu, lub w postaci proszku (szczegółowy wykaz towarów zwanych „towarami wrażliwymi” znajduje się w załączniku numer 13 do ustawy o podatku od towarów i usług). Kaucja mogła być złożona przez każdy podmiot, który dokonuje dostawy towarów, o których mowa w załączniku nr 13 do ustawy o podatku od towarów i usług, pod warunkiem że podmiot ten nie ma zaległości podatkowych w podatkach stanowiących dochód budżetu państwa. Warunek nieposiadania zaległości podatkowych oceniał według stanu na dzień składania kaucji.

7 Ustawa z dnia 26 lipca 2013 r. o zmianie ustawy o podatku od towarów i usług oraz niektórych innych ustaw (Dz.U. z 2013 r., poz. 1027). 
Oceny tzw. odpowiedzialności solidarnej są bardziej wyraziste niż odwróconego obciążenia. Wprowadzając ten mechanizm, oczekiwano przede wszystkim zniechęcenia potencjalnych nabywców do nabywania towarów w przypadkach zwiększonego ryzyka uwikłania się w transakcję stanowiącą oszustwo podatkowe (popełniane przez zbywcę). Gdyby jednak do oszustwa doszło, zakładano zrekompensowanie Skarbowi Państwa strat z niego wynikających bądź poprzez mechanizm odpowiedzialności solidarnej, bądź poprzez odzyskanie pieniędzy ze złożonej kaucji. Kaucja była istotnym elementem działania tego mechanizmu. Podmioty, które ją złożyły, były ujmowane w specjalnym wykazie prowadzonym przez Ministra Finansów. Miało to istotne znaczenie praktyczne, gdyż skutkowało domniemaniem działania $\mathrm{w}$ dobrej wierze w przypadku nabywania towarów objętych mechanizmem solidarnej odpowiedzialności od podmiotów wymienionych w wykazie prowadzonym przez Ministra Finansów. Jednakże właśnie mechanizm kaucji gwarancyjnej okazał się najsłabszym elementem „odpowiedzialności solidarnej”. Zanotowano przypadki wykorzystania go przez dokonujących oszustw podatkowych, którzy składając kaucje, uzyskiwali w ten sposób status „podmiotu zaufanego”, znajdującego się w wykazie publikowanym przez Ministra Finansów ${ }^{8}$. Okazało się to możliwe, gdyż wysokość kaucji była po prostu zbyt niska w stosunku do zysków z oszukańczego procederu, które zazwyczaj istotnie przekraczały wartość wpłaconej kaucji. Drugą przyczyną było następcze działanie organów podatkowych, wszczynających postępowania kontrolne lub podatkowe związane $z$ dostawami zabezpieczonymi kaucją gwarancyjną zazwyczaj z dużym opóźnieniem. Z tego powodu zdarzało się również odzyskanie przez podatników kaucji po dokonaniu oszustwa w podatku VAT.

Oprócz rozległych, polegających na wprowadzaniu nowych rozwiązań instytucjonalnych, stosowano też bardziej tradycyjne rozwiązania, np. rozszerzono od 1 stycznia 2015 r. ${ }^{9}$ katalog czynności podlegających obowiązkowi prowadzenia ewidencji przy zastosowaniu kas rejestrujących. W stosunku do poprzednio obowiązującego rozporządzenia katalog czynności

8 Opinia nr 8/2015 Rady Konsultacyjnej Prawa Podatkowego z dnia 20 sierpnia 2015 r. w sprawie Propozycji Zespołu ds. podatków pośrednich Rady Konsultacyjnej Prawa Podatkowego dotyczących rozwiązań ograniczających możliwość popełniania oszustw VAT.

9 Rozporządzenie Ministra Finansów z dnia 4 listopada 2014 r. w sprawie zwolnień z obowiązku prowadzenia ewidencji przy zastosowaniu kas rejestrujących (Dz.U. z 2014 r., poz. 1544; tekst jedn. Dz.U. z 2016 r., poz. 1215). 
wyłączonych ze zwolnień poprzez objęcie obowiązkiem prowadzenia ewidencji przy zastosowaniu kas rejestrujących został wyraźnie zawężony ${ }^{10}$. Według szacunków Ministerstwa Finansów w wyniku zmiany tej regulacji, polegającej po prostu na poszerzeniu zakresu podmiotów zobowiązanych do stosowania kas fiskalnych, dochody budżetu państwa w 2016 r. wzrosły o $120 \mathrm{mln} \mathrm{zf}^{11}$. Obszar obowiązków sprawozdawczych i rozwiązań o charakterze administracyjnym był obszarem szczególnego zainteresowania ustawodawcy w kolejnych latach.

\section{WYSIEEK LEgISLACYJNY W NOWEJ KADENCJI PARLAMENTU (PO 2015 R.)}

Widoczne zwiększenie aktywności legislacyjnej, które nastąpiło po roku 2015 r., można uznać za wynik zmian priorytetów w polityce podatkowej, co wiązało się z wejściem do dyskursu politycznego pojęcia „luki VAT”, które - nieraz w bardzo uproszczonej formie - zagościło w publicystyce.

Jednym z pierwszych wprowadzonych przez nowy skład sejmu rozwiązań, które miały prowadzić do dalszego uszczelniania systemu podatku od towarów i usług, było wprowadzanie obowiązkowego, a nie na wezwanie organu podatkowego, raportowania danych z ewidencji zakupu i sprzedaży VAT, za pomocą środków komunikacji elektronicznej. Obowiązek ten przybrał formę jednolitego pliku kontrolnego (JPK) składanego za okresy miesięczne, w terminie do 25. dnia następnego miesiąca. Wprowadzono go Ustawą z dnia 13 maja 2016 r. o zmianie ustawy - Ordynacja podatkowa oraz niektórych innych ustaw ${ }^{12}$. Rozwiązanie to było wprowadzane stopniowo. Począwszy od lipca 2016 r., zobowiązano do tego podatników czynnych VAT posiadających status „dużego przedsiębiorcy” w rozumieniu ustawy o swobodzie działalności gospodarczej. Z przekazywania „plików JPK” do końca roku 2016 r. byli zwolnieni mali i średni przedsiębiorcy, a do końca 2017 r. mikro przedsiębiorcy. Ostatecznie, począwszy od lutego 2018 r., objęto obowiązkiem raportowania JPK_VAT wszystkich podatników VAT.

10 Rozporządzenie Ministra Finansów z dnia 29 listopada 2012 r. w sprawie zwolnień z obowiązku prowadzenia ewidencji przy zastosowaniu kas rejestrujących (Dz.U. z 2012 r., poz. 1382), które obowiązywało w latach 2013-2014.

11 Informacja o wynikach kontroli NIK, KBF.410.008.01.2016, Nr ewid. P/16/010, Warszawa 2017, s. 13.

12 Ustawa o zmianie ustawy - Ordynacja podatkowa oraz niektórych innych ustaw z dnia 13 maja 2016 r. (Dz.U. z 2016 r., poz. 846). 
Choć raportowanie w formie elektronicznej stanowi bez wątpienia dodatkowy obowiązek administracyjny, jego wprowadzenie odbyło się bez większych zakłóceń. W pierwszym miesiącu jego obowiązywania złożono 1703271 plików od 1508458 przedsiębiorców, tj. z obowiązku wywiązało się 94,5\% zobowiązanych. Plików JPK nie złożyło zaledwie 88163 zobowiązanych do tego podatników ${ }^{13}$.

Co zaskakujące, skuteczność plików JPK w zwiększaniu wpływów budżetowych nadal nie doczekała się kompleksowej oceny. W sferze publicznej można znaleźć jedynie wyrywkowe informacje na temat wpływu jednolitego pliku kontrolnego na wpływy budżetowe i pracę administracji. Według ogólnych informacji przedstawionych przez Ministerstwo Finansów podczas jednej z konferencji prasowych w latach 2017-2018 dane z JPK_VAT miały pozwolić na identyfikację nieprawidłowości oraz wyegzekwowanie zaległości w podatku od towarów i usług na kwotę łączną ponad 2 mld zł ${ }^{14}$.

Natomiast implementacja tego rozwiązania do pracy administracji podatkowej i skarbowej, a następnie krajowej administracji skarbowej przebiegała zaskakująco wolno. Zgodnie z dostępnymi danymi w 2016 r. JPK_VAT został wykorzystany jedynie w dwóch kontrolach podatkowych oraz w znikomym stopniu w czynnościach sprawozdających (0,01\% wszystkich prowadzonych czynności), a w postępowaniach podatkowych w ogóle nie został wykorzystany. Symboliczne było wykorzystanie jednolitych plików kontrolnych przekazywanych na żądanie organów podatkowych ${ }^{15}$. Skromnie sięgano po JPK_VAT w drugim półroczu 2016 r., tj. w pierwszych miesiącach, w których dla dużych przedsiębiorców prowadzących ewidencję przy użyciu programów komputerowych powstał obowiązek przekazywania jednolitego pliku kontrolnego dla ewidencji zakupu i sprzedaży VAT bez wezwania organu podatkowego ${ }^{16}$. W okresie od 1 lipca 2016 r. do 30 czerwca 2018 r., kiedy

${ }^{13}$ http://www.podkarpackie.kas.gov.pl/izba-administracji-skarbowej-w-rzeszowie/ wiadomosci/aktualnosci/ (dostęp: 14.04.2019); Podsumowanie pierwszego miesiąca przesyłania JPK przez wszystkich czynnych podatników VAT, Ministerstwo Finansów, marzec 2018.

14 J. Sarnowski, P. Selera, Zmniejszenie luki VAT w Polsce w latach 2016-2017: przyczyny - środki - dalsze perspektywy, Polski Instytut Ekonomiczny, Warszawa 2018, s. 24.

15 Informacja o wynikach kontroli NIK, KBF.430.002.2019, Nr ewid. 80/2019/P/18/011/ KBF, Warszawa 2019, s. 42.

16 Informacja o wynikach kontroli NIK, KBF.430.002.2019, Nr ewid. 80/2019/P/18/011/ KBF, Warszawa 2019. Wartość ustalona na podstawie analiz danych za okres od stycznia do października 2018 r. przeprowadzonych do 25 stycznia 2019 r. Informacja o wynikach kontroli NIK, LKR.430.005.2018, Nr ewid. 11/2019/P/18/077/LKR, Warszawa 2019. Kontrolą objęto okres od 1 lipca 2016 r. do 30 czerwca 2018 r. 
to obowiązek przedłożenia ewidencji w formie plików JPK obowiązywał dużych przedsiębiorców, służby skarbowe przeprowadziły z ich wykorzystaniem zaledwie: 242 kontrole podatkowe, 17 kontroli celno-skarbowych, 71 czynności sprawdzających i 5 postępowań kontrolnych w trybie ustawy o kontroli skarbowej ${ }^{17}$. W zakończonych w 2018 r. 1300 postępowaniach, kontrolach podatkowych, kontrolach celno-skarbowych i czynnościach sprawdzających pobrano 2000 plików, a 6400 plików w okresie od stycznia do września 2019 r. w 4500 postępowaniach, kontrolach i czynnościach sprawdzających. W ich wyniku stwierdzono nieprawidłowości na kwotę 98,5 mln zł w $2018 \mathrm{r}$. oraz na kwotę 317,2 mln zł w okresie od stycznia do września 2019 r. ${ }^{18}$ Stopień wykorzystania JPK_VAT zwiększał się w kolejnych latach. W czynnościach sprawdzających z 11,8\% w 2017 r. do 29,6\% w pierwszej połowie 2018 r., a w kontrolach rozliczeń VAT odpowiednio z 2,6\% do 13\%. Wskutek tego podatnicy złożyli w 2017 r. korekty na kwotę 34,1 mln zł (co stanowiło 11,5\% wszystkich korekt wynikających z czynności sprawdzających w zakresie VAT), a w I połowie 2018 r. - na kwotę 92,8 mln zł (jedna piąta korekt po czynnościach sprawdzających w zakresie VAT). W 2017 i w pierwszej połowie 2018 r. dane z plików JPK_VAT zostały wykorzystane w 5,6\% kontroli rozliczeń VAT przeprowadzonych przez urzędy skarbowe, urzędy kontroli skarbowej i urzędy celno-skarbowe (które od 1 marca 2017 r. zastąpiły Urzędy Kontroli Skarbowej). W ich wyniku ujawniono nieprawidłowości na 266,9 mln zł, co stanowiło 1\% kwoty wszystkich nieprawidłowości stwierdzonych podczas kontroli rozliczeń VAT w tym okresie. Zaskoczenie może budzić fakt, że najsłabiej wykorzystywano JPK_VAT w postępowaniach podatkowych - w 0,1\% w 2017 r. i 0,9\% w pierwszym półroczu 2018 r. Wskutek tego tzw. dodatkowe ustalenia organów podatkowych, czyli zwiększenia zobowiązań podatkowych kontrolowanych podmiotów, wyniosły $2,9 \mathrm{mln} \mathrm{zł}, \mathrm{w}$ tym 1,6 mln zł zatrzymanych wypłat nienależnych zwrotów VAT (co jednak nie przekraczało 1\% całości ustaleń w wyniku postępowań prowadzonych w tym okresie) ${ }^{19}$.

17 Informacja o wynikach kontroli NIK, KBF.430.002.2019, Nr ewid. 80/2019/P/18/011/ KBF, Warszawa 2019, s. 42.

${ }^{18}$ Informacja o wynikach kontroli NIK, KBF.410.006.01.2019, P/19/011, Warszawa 2020, s. 7.

19 NIK ma zastrzė̇enia do wdrażania JPK, „Dziennik Gazeta Prawna” 26.11.2018, https://podatki.gazetaprawna.pl/artykuly/1365203,zastrzezenia-nik-do-mf-dot-wdroze nia-jpk.html (dostęp: 14.04.2019). 
Wydaje się, że istotną cezurą dla skuteczności wykorzystania danych zawartych w plikach JPK było rozpoczęcie przez Ministerstwo Finansów, począwszy od 2017 r., automatycznej analizy prawidłowości przekazanych przez podatników w JPK rozliczeń w VAT. W przypadku stwierdzenia tzw. rozbieżności $\mathrm{w}$ takich przekazanych plikach do podatników kierowane są powiadomienia (z poziomu centralnego lub przez właściwy urząd skarbowy) o potrzebie weryfikacji rozliczenia i ewentualnej możliwości złożenia korekty bez konsekwencji podatkowych, w tym karnych skarbowych. W 2017 r. zidentyfikowano 405200 tego typu przypadków na kwotę 79 mld zł, a w 2018 r., do rozliczenia JPK_VAT za sierpień włącznie, kwotę 77,4 mld zł. Ministerstwo Finansów wysłało w 2017 r. 38200 powiadomień o możliwych nieprawidłowościach w formie SMS lub wiadomości e-mail ${ }^{20}$. W okresie styczeń-wrzesień 2018 r. liczba wysłanych powiadomień głównie w formie SMS i wiadomości e-mail wyniosła $349900^{21}$. Po otrzymaniu takiego powiadomienia podatnicy mogli samodzielnie sprawdzić swoje rozliczenie VAT i złożyć korektę deklaracji. Wykorzystując JPK_ VAT, Ministerstwo Finansów, począwszy od 2017 r., cyklicznie generuje także zestawienia podatników, którzy w rozliczeniu VAT deklarują „zerowe" obroty albo nie składają w ogóle deklaracji VAT, a jednocześnie w tożsamym okresie występują jako wystawcy faktur VAT. Za okres od stycznia do grudnia 2017 r. zidentyfikowano 152700 faktur wystawionych przez podmioty niezarejestrowane dla celów podatku VAT lub podmioty, które nie złożyły deklaracji lub wykazały w deklaracjach „zerowe” obroty. Kwota podatku VAT wynikająca z tych faktur wyniosła $436,5 \mathrm{mln}$ zł. Za okres od stycznia do września 2018 r. zidentyfikowano 298000 takich faktur z kwotą podatku VAT 674,7 mln zł, a w całym 2018 r. zidentyfikowano 593000 takich faktur $\mathrm{z}$ kwotą podatku VAT 1,337,2 mln zł. Na podstawie informacji o transakcjach ujawnionych w JPK_VAT prowadzone były również analizy ukierunkowane na identyfikację uczestników tzw. transakcji karuzelowych, do objęcia czynnościami sprawdzającymi i kontrolami podatkowymi lub celno-skarbowymi. W efekcie prowadzonych od połowy 2016 r. 234 analiz i ustaleń urzędów skarbowych wstrzymano wypłatę zwrotów VAT w kwocie $277,9 \mathrm{mln}^{22}$. Kwota zwiększonego podatku należnego VAT z korekt

${ }^{20}$ Informacja o wynikach kontroli NIK, KBF.430.002.2019, Nr ewid. 80/2019/P/18/011/ KBF, Warszawa 2019, s. 51.

${ }^{21}$ Za okres styczeń-marzec oprócz powiadomień w formie SMS lub wiadomości e-mail wysyłane były również powiadomienia w formie papierowej.

${ }^{22}$ Informacja o wynikach kontroli NIK, KBF.410.006.01.2019, P/19/011, Warszawa 2020, s. 6 . 
złożonych przez podatników w efekcie analiz danych wykazanych w plikach JPK_VAT wyniosła w 2017 r. 6707,8 mln zl, a w 2018 r. 6227,2 mln $\mathrm{zł}^{23}$. Z kolei kwota korekty podatku naliczonego do odliczenia przez podatników, u których ustalono na podstawie raportów automatycznych rozbieżności, wyniosła w 2017 r. 3816,3 mln zł, a w 2018 r. 4519,7 mln zł. Odpowiednio korekta podatku zadeklarowanego do wpłaty wyniosła 701,9 mln zł oraz 617,7 mln zł. Podmioty, u których zidentyfikowano rozbieżności, zwiększyły zadeklarowany za 2018 r. podatek do wpłaty o 743,7 mln zł, a za okres od stycznia do września 2019 r. o 273,4 mln zł (dane wstępne) ${ }^{24}$. Tylko w czynnościach sprawdzających przeprowadzonych z udziałem podatników w trybie przepisów Działu V ustawy Ordynacja podatkowa wykorzystano w 2017 r. pliki JPK_VAT w 83 200, tj. w 11,8\%, a w pierwszym półroczu 2018 r. w 114100 takich czynnościach, tj. w 29,6\% wszystkich czynności sprawdzających w zakresie VAT przeprowadzonych w tym okresie. Wzrosła także kwota ustaleń dokonanych w wyniku przeprowadzonych czynności sprawdzających z wykorzystaniem JPK_VAT z 46,1 mln zł w 2017 r. do 103,5 mln zł w pierwszym półroczu 2018 r. Kwoty ustalone w wyniku czynności sprawdzających przeprowadzonych z wykorzystaniem plików JPK_VAT stanowiły w 2017 r. 9,6\%, a w pierwszym półroczu 2018 r. $16,6 \%$ ustaleń dokonanych w wyniku czynności sprawdzających w zakresie podatku VAT ${ }^{25}$.

Trzeba zauważyć, że planowana jest dalsza ewolucja plików JPK_VAT. Kolejnym etapem ma być połączenie go ze „zwykłą” deklaracją podatkową VAT $^{26}$. Dane podatkowe wykazywane dotychczas w VAT-7 i VAT-7K będą przesyłane wtedy wyłącznie w pliku JPK_VAT razem z ewidencją VAT. W ten sposób powstanie jedna struktura dokumentu (tzw. schema) podzielona na część ewidencyjną i deklaracyjną. Nowe deklaracje mają obowiązywać już od 1 kwietnia 2020 r. dużych podatników, a od 1 lipca 2020 r. pozostałych ${ }^{27}$.

23 Wartość ustalona na podstawie przeprowadzonych do 25 stycznia 2019 r. analiz danych za okres od stycznia do października $2018 \mathrm{r}$.

${ }^{24}$ Informacja o wynikach kontroli NIK, KBF.410.006.01.2019, Nr ewid. P/19/011, Warszawa 2020, s. 5.

25 Informacja o wynikach kontroli NIK, KBF.430.002.2019, Nr ewid. 80/2019/P/18/011/ KBF, Warszawa 2019, s. 53.

26 Zmiany wprowadzone Ustawą z dnia 4 lipca 2019 r. o zmianie ustawy o podatku od towarów i usług oraz niektórych innych ustaw (Dz.U. z 2019 r., poz. 1520).

27 Rozporządzenie Ministra Finansów, Inwestycji i Rozwoju z dnia 15 października 2019 r. w sprawie szczegółowego zakresu danych zawartych w deklaracjach podatkowych i w ewidencji w zakresie podatku od towarów i usług (Dz.U. z 2019 r., poz. 1988). 
Bez względu na przyszłe losy jednolity plik kontrolny, w powszechnym odbiorze, wydaje się dalej personifikować walkę z „luką w VAT”. Trzeba jednak wskazać na pewną istotną wadę tego narzędzia (i jego potencjalnych następców) - skuteczność JPK jest ograniczona tylko do obrotu pomiędzy podmiotami prowadzącymi działalność gospodarczą (w praktyce wystawiającymi faktury lub dokumenty $z$ nimi równoważne). Tymczasem sprzedaż dokonywana na rzecz ostatecznych konsumentów podlega zasadniczo rejestracji za pomocą kas fiskalnych. Objęcie tego typu transakcji (Business to Consumer - B2C) pozwala na sprawowanie nadzoru nad całym obrotem VAT dokonywanym w ramach działalności gospodarczej w kraju. Rejestracja obrotów przez podatników VAT na rzecz ostatecznych konsumentów opiera się na kasach rejestrujących. Elektronizacja tego rozwiązania umożliwia osiągnięcie w tym zakresie rezultatów porównywalnych z JPK_VAT, polegających na automatycznym przesyłaniu informacji o rejestrowanych transakcjach sprzedaży organom podatkowym. Tego typu kasy fiskalne zwane są kasami online. Możliwość ich stosowania została wprowadzona Ustawą z dnia 15 marca 2019 r. o zmianie ustawy o podatku od towarów i usług oraz ustawy - Prawo o miarach ${ }^{28}$. Rozwiązanie zwane potocznie „kasami fiskalnymi online" opiera się na wprowadzeniu stosowania przez zobowiązanych do tego podatników podatku VAT nowego rodzaju kas rejestrujących (tzw. kas online) umożliwiających, oprócz stosowanego już obecnie zapisu w pamięci kasy, również przekazywanie w sposób ciągły, zautomatyzowany i bezpośredni informacji z kas rejestrujących, czyli prowadzonej przez nie ewidencji, oraz o zdarzeniach mających znaczenie dla pracy kas, które zaistniały podczas ich użytkowania, do systemu teleinformatycznego prowadzonego przez Szefa Krajowej Administracji Skarbowej, nazwanego w tekście ustawy „Centralnym Repozytorium Kas”. Zgodnie z zapisami projektu z tytułu wprowadzenia kas fiskalnych przekazujących dane w formie elektronicznej w roku 2018 ma wpłynąć dodatkowo 180,3 mln zł, a w roku 2019 - 349,3 mln ${ }^{29}$. Brak w sferze publicznej informacji o realizacji tych zamierzeń, natomiast w okresie od 1 maja do 30 listopada 2019 r. zaewidencjonowano na 81100 kasach online sprzedaż brutto w kwocie 19,9 mld $\mathrm{z}^{30}$.

${ }^{28}$ Dz.U. z 2019 r., poz. 675; Rozporządzenie Ministra Finansów z dnia 29 kwietnia 2019 r. w sprawie kas rejestrujących (Dz.U. z 2019 r., poz. 816).

${ }^{29}$ Druk sejmowy nr 2503 z dnia 26 kwietnia 2018 r. Ocena Skutków Regulacji, s. 4; na cały okres 2018-2028 wpływy oszacowano na 11 038,9 mln zł.

${ }^{30}$ Informacja o wynikach kontroli NIK, KBF.410.006.01.2019, P/19/011, Warszawa 2020, s. 10 . 
Ustawodawca przewidział również możliwość prowadzenia ewidencji sprzedaży przy użyciu innego typu kas o charakterze stricte elektronicznym - kas online mających postać oprogramowania; są to tzw. kasy wirtualne. Nie mają one w ogóle postaci fizycznej, lecz są to de facto programy komputerowe. Brak rozporządzenia wykonawczego określającego wymogi techniczne uniemożliwia jeszcze użytkowanie tego typu kas $^{31}$.

Warto też zauważyć, że niemal jednocześnie z wprowadzeniem jednolitego pliku kontrolnego, z dniem 15 lipca 2016 r. weszła w życie zmiana ustawy o podatku od towarów i usług, która wprowadziła klauzulę nadużycia prawa w VAT (art. 5 ust. 4 i 5 ustawy o podatku od towarów i usług). Wprowadzenie tej instytucji na grunt systemu podatku VAT umożliwiło nie tylko wydawanie przez Ministra Finansów, a po 1 marca 2017 r. Szefa Krajowej Administracji Skarbowej opinii, ale przede wszystkim stanowi podstawę dla Dyrektora Krajowej Informacji Skarbowej do odmowy wydania interpretacji indywidualnej w zakresie tych elementów stanu faktycznego lub zdarzenia przyszłego, co do których istnieje uzasadnione przypuszczenie, że mogą stanowić nadużycie prawa, o którym mowa w art. 5 ust. 5 ustawy o podatku od towarów i usług. W tych sprawach wydawane są postanowienia o odmowie wszczęcia postępowania w sprawie wniosku o wydanie interpretacji indywidualnej. Rozwiązanie to nie przekłada się w sposób bezpośredni na wzrost wpływów podatkowych, ale stanowi użyteczne narzędzie do eliminowania niektórych mechanizmów optymalizacyjnych z obrotu prawnego.

Zazwyczaj pomijaną w opracowaniach, ale istotną systemowo zmianą o jednoznacznym celu - ograniczenia szarej i czarnej strefy - było obniżenie z 15 tys. euro do 15 tys. złotych limitu wartości transakcji pomiędzy przedsiębiorcami, powyżej którego istnieje obowiązek dokonania (przyjęcia) płatności poprzez rachunek płatniczy. Zmiana została wprowadzona Ustawą z dnia 13 kwietnia 2016 r. o zmianie ustawy o podatku dochodowym od osób fizycznych, podatku dochodowym od osób prawnych oraz o zmianie ustawy o swobodzie działalności gospodarczej ${ }^{32}$.

Oczekiwano, że obniżenie tego limitu przyczyni się do zwiększenia dochodów budżetu państwa poprzez ograniczenie fikcyjnych transakcji i zmniejszenie szarej strefy. Jednocześnie ustawa wprowadziła zmiany

31 Artykuł 111b ust. 3 pkt 2 ustawy o podatku od towarów i usług.

32 Ustawa z dnia 13 kwietnia 2016 r. o zmianie ustawy o podatku dochodowym od osób fizycznych, ustawy o podatku dochodowym od osób prawnych oraz ustawy o swobodzie działalności gospodarczej (Dz.U. z 2016 r., poz. 780). 
w podatkach dochodowych polegające na braku prawa do zaliczenia do kosztów uzyskania przychodów kwoty płatności, a także konieczności zmniejszenia takich kosztów o kwotę płatności, w przypadku gdy podatnik dokonałby płatności z pominięciem rachunku płatniczego. Ustawodawca zakładał, że powszechność płatności elektronicznych wpływa na ograniczanie rozmiaru szarej strefy w gospodarce i ograniczanie transakcji fikcyjnych zaliczanych do kosztów uzyskania przychodów, a w rezultacie powodujących zaniżenie podstawy podlegającej opodatkowaniu podatkiem dochodowym. W sferze publicznej brakuje oceny skutków wprowadzenia tych regulacji. Nie ulega natomiast wątpliwości, że systematyczny spadek tzw. gotówkowej szarej strefy (niezarejestrowanej wartości dodanej brutto związanej z płatnościami gotówkowymi) przyczyniał się do stopniowego obniżania luki VAT w Polsce ${ }^{33}$. Sama zaś tzw. gotówkowa szara strefa jest szacowana na poziomie 9,9\% PKB (228,7 mld zl) jeszcze w roku $2018^{34}$. Bez wątpienia ograniczenie obrotu gotówkowego ułatwiło wprowadzenie kolejnych rozwiązań „uszczelniających” podatek VAT, takich jak podzielona płatność czy STIR. Wydaje się, że tego typu działania przynosiły pewne skutki, szczególnie w odniesieniu do towarów tzw. wrażliwych podlegających opodatkowaniu podatkiem akcyzowym, zasadnicze jednak znaczenie dla ograniczenia szarej strefy, a w konsekwencji wzrostu wpływów podatkowych w tych obszarach miały zmiany legislacyjne wprowadzone w ramach trzech pakietów: paliwowego, energetycznego oraz przewozowego. Pod tymi łatwo wpadającymi w ucho nazwami projektów kryją się istotne zmiany w kilkudziesięciu ustawach, począwszy od ustawy o podatku od towarów i usług, na prawie energetycznym kończąc. Pakiet paliwowy, po wejściu w życie 1 sierpnia 2016 r., koncentrował się na przepisach mających na celu utrudnienie wyłudzenia VAT podczas importu wewnątrzwspólnotowego, m.in. na przyznawaniu koncesji na obrót paliwami tylko tym podmiotom zagranicznym, które mają w kraju oddział lub siedzibę. Jednocześnie generalnie skrócono termin zapłaty podatku VAT z kwartału po dalszej sprzedaży do pięciu dni po sprowadzeniu paliwa do Polski. Zmodyfikowano również metodę ustalania podstawy opodatkowania. Zamiast deklarowanej wartości przewożonego towaru stała się nią kwota ustalana na podstawie cen hurtowych paliw silnikowych publikowanych

33 Szara strefa w Polsce, Zespół Analiz Ekonomiczny Ernst and Young, Warszawa 2020, s. 5, https://www.ey.com/Publication/vwLUAssets/Szara_strefa_w_Polsce_final/\$File/Szara\% 20strefa\%20w\%20Polsce_final.pdf (dostęp: 19.02.2020).

34 Ibidem, s. 6. 
w Biuletynie Informacji Publicznej lub właściwej ceny na stronach Ministerstwa Finansów. Przeniesiono też ciężar w zakresie odpowiedzialności z nabywców (którymi mogły być dawniej spółki zarejestrowane w krajach nieobjętych jurysdykcją unijną) na zarejestrowanych odbiorców i składy podatkowe ${ }^{35}$. Pakiet energetyczny w radykalny sposób wpłynął na organizację rynku paliw w Polsce. Najistotniejsze wydają się zmiany w zakresie koncesjonowania obrotu paliwami oraz kontroli jakości paliw ${ }^{36}$. Trzecim istotnym elementem był tzw. pakiet transportowy ${ }^{37}$, którego zasadniczą treścią było wdrożenie, począwszy do 18 kwietnia 2017 r., dokładnego monitorowania obrotu paliwami, tytoniem czy alkoholami skażonymi (tzw. towary wrażliwe $)^{38}$. Obie te regulacje wprowadziły także wysokie sankcje za ich naruszenia. Za działalność bez posiadanej koncesji na obrót paliw lub z jej naruszeniem zunifikowana kara wynosi aż 5 mln zł, przy jednoczesnym zagrożeniu karą pozbawienia wolności od 6 miesięcy do 5 lat. Pakiet transportowy wprowadził wiele kar za uchybienia w przewozie paliw, którego plagą były dotychczas tzw. znikające transporty, sięgające $46 \%$ wartości brutto towaru przewożonego podlegającego obowiązkowi zgłoszenia, ale nie mniej niż 20000 zł. W odniesieniu do tych - odnoszących się początkowo do jednego sektora, ale jednak dość szerokich - zmian uprawniona wydaje się teza, że ustawodawca osiągnął cele, których oczekiwał po nowelizacji. Wskazują na to choćby wyniki upublicznionej przez Ministerstwo Finansów analizy wybranej grupy podmiotów posiadających koncesje na obrót paliwami ciekłymi oraz deklaracji podatkowych VAT-7 i VAT-14. Jej wyniki wskazują, że w pierwszym kwartale 2017 r. obrót deklarowany przez podmioty w stawce podstawowej $23 \%$ wzrósł z 40,7 mld do 52,5 mld zł. Natomiast wzrost zadeklarowanej do wpłaty na rzecz organów podatkowych przez te podmioty kwoty podatku VAT wyniósł $966 \mathrm{mln} \mathrm{zl}^{39}$.

35 Ustawa z dnia 7 lipca 2016 r. o zmianie ustawy o podatku od towarów i usług oraz niektórych innych ustaw (Dz.U. z 2016 r., poz. 1052).

36 Ustawa z dnia 22 lipca 2016 r. o zmianie ustawy - Prawo energetyczne oraz niektórych innych ustaw (Dz.U. z 2016 r., poz. 1165).

37 Ustawa z dnia 9 marca 2017 r. o systemie monitorowania drogowego i kolejowego przewozu towarów oraz obrotu paliwami opałowymi (Dz.U. z 2017 r., poz. 708).

38 Mowa o tzw. systemie SENT, zgodnie z którym konieczne jest każdorazowe zgłoszenie planowanego przewozu towaru wrażliwego łącznie z podaniem trasy oraz daty transportu. Podmiotami ponoszącymi odpowiedzialność w wyniku wdrożenia systemu są nie tylko odbiorca, ale również firma transportowa i kierowca.

39 Walka z szara strefa. Wpływ regulacji na branżę paliw płynnych, Polska Organizacja Przemysłu i Handlu Naftowego, PWC, Warszawa 2018, s. 24. 
Inne analizy wykazały, że podmioty posiadające koncesję na obrót paliwami i składające pliki JPK_VAT wpłaciły w pierwszym półroczu 2017 r. podatek VAT wyższy o ok. 2,5 mld zł niż w pierwszym półroczu $2016 \mathrm{r}^{40}$

W odpowiedzi na złożoną przez posła Michała Jarosa interpelację nr 18810 z dnia 26 stycznia 2018 r. w sprawie uszczelnienia systemu VAT wskazano natomiast, że nowe regulacje zwiększające skuteczność nadzoru państwa nad obrotem paliwami sprowadzanymi do Polski i umożliwiające bieżące monitorowanie obrotu wpłynęły na wzrost legalnej sprzedaży i przełożyły się na zwiększenie wpływów z tytułu podatku VAT - w 2017 r. o ponad $4 \mathrm{mld} \mathrm{zt}^{41}$.

Analogiczne konstrukcyjnie rozwiązania zostały zastosowane w odniesieniu do innych obszarów podlegających podatkowi akcyzowemu, tj. obrotu alkoholem - jako tzw. pakiet spirytusowy ${ }^{42}$ oraz wyrobów tytoniowych - tzw. pakiet tytoniowy ${ }^{43}$. Podobnie jak pakiet paliwowy, odnosiły się one do podatku akcyzowego i zmniejszenia zakresu szarej strefy w obrocie tymi towarami. Niewątpliwe sukcesy w tym zakresie, polegające na wzroście oficjalnie notowanej sprzedaży towarów „akcyzowych”, powodowały wzrost wpływów z podatku VAT. Wprowadzając w życie projekt pakietu tytoniowego, Ministerstwo Finansów szacowało, że z tego obszaru do Skarbu Państwa nie wpływa ok. 6 mld zł z tytułu niezapłaconego podatku akcyzowego i VAT, co przekładało się na szarą strefę w szeroko pojętej branży tytoniowej w wysokości 14,6\% krajowej konsumpcji ${ }^{44}$.

Potoczne określenie, tzw. pakiet spirytusowy, zyskała ustawa zmieniająca ustawę o podatku akcyzowym ${ }^{45}$. Weszła ona w życie w dniu 27 maja 2017 r., ujednolicając zasady dotyczące dopuszczalnych typów alkoholu skażonego całkowicie. Straty Skarbu Państwa w tym obszarze szacowano na kwotę pomiędzy 1,6 mld a $3 \mathrm{mld} \mathrm{z}^{46}$.

\footnotetext{
40 Informacja o wynikach kontroli NIK, KBF.430.003.2018, s. 16.

41 Pismo z dnia 9 lutego 2018 r., znak DKA8.054.2.2018.

42 Ustawa $\mathrm{z}$ dnia 7 kwietnia 2017 r. o zmianie ustawy o podatku akcyzowym (Dz.U. z 2017 r., poz. 937).

43 Ustawa z dnia 27 października 2017 r. o zmianie ustawy o podatku akcyzowym oraz ustawy o organizacji niektórych rynków rolnych (Dz.U. z 2017 r., poz. 2216).

${ }^{44}$ Uznawano, że szara strefa w tym obszarze maleje - w 2015 r. szacowano ją na ok. $18,2 \%$ konsumpcji.

45 Ustawa z dnia 7 kwietnia 2017 r. o zmianie ustawy o podatku akcyzowym (Dz.U. z 2017 r., poz. 937).

${ }^{46}$ Koniec skażonego spirytusu na bazarach?, https://biznes.gazetaprawna.pl/arty kuly/979794,teraz-spirytus-w-pakiecie-skazony.html (dostęp: 14.04.2019).
} 
Działania te przynajmniej w początkowym okresie przyniosły obserwowalne rezultaty. Na przykład według badań niezależnych ekspertów szara strefa na rynku wyrobów tytoniowych w roku 2015 wynosiła 19\%, tymczasem dzięki działaniom służb skarbowych w drugim kwartale $2017 \mathrm{r}$. spadła do niecałych $14 \%{ }^{47}$. Według szacunków Krajowej Administracji Skarbowej (KAS) szara strefa w obszarze wyrobów alkoholowych w roku 2016 r. zmniejszyła się z 9\% do 8\%. W roku 2014 wpływy wyniosły 6,6 mld zł, a w 2016 - 7,6 mld złotych. Wpływy z tytułu podatku akcyzowego wzrosły o 1 mld $\mathrm{z}^{48}$.

Dalsze starania ustawodawcy o zwiększenie wpływów z podatku VAT przyjęły formę nowelizacji samej ustawy o podatku od towarów i usług o bardzo kompleksowym charakterze. Z dniem 1 stycznia 2017 r. wszedł w życie szeroki pakiet zmian uszczelniających VAT wprowadzony Ustawą z dnia 1 grudnia 2016 r. o zmianie ustawy o podatku od towarów i usług oraz niektórych innych ustaw (tzw. pakiet uszczelniający) ${ }^{49}$. Zakres wprowadzonych zmian w sposób wyraźny odbiegał od praktyki sektorowych bądź wąskich, o technicznym charakterze zmian legislacyjnych. Dodatkowo część modyfikacji można uznać za niemal rewolucyjne rozwiązania, często zrywające $\mathrm{z}$ dotychczasową wieloletnią praktyką w obszarze podatku od towarów i usług. Za takie można uznać:

- modyfikacje w zakresie rejestrowania i wyrejestrowywania podmiotów dla potrzeb VAT;

- niedokonywanie rejestracji podmiotów, które złożyły zgłoszenie rejestracyjne, a w wyniku weryfikacji informacji zawartych w zgłoszeniu rejestracyjnym okazało się, że podmioty te nie istnieją lub mimo podjęcia udokumentowanych prób nie ma możliwości skontaktowania się z nimi albo $\mathrm{z}$ ich pełnomocnikami;

- likwidacje rozliczeń kwartalnych dla podatników innych niż mali podatnicy (w rozumieniu ustawy o podatku od towarów i usług) oraz brak możliwości rozliczeń kwartalnych dla nowych podatników w okresie pierwszych dwunastu miesięcy od rejestracji jako podatnicy VAT czynni;

${ }^{47}$ Raport: Wplyw Krajowej Administracji Skarbowej na przeciwdziałanie szarej i czarnej strefie, [w:] Przeciwdziałanie szarej strefie w Polsce, UN Global Compact, Warszawa 2017, s. 35 (https://ungc.org.pl/strefa-wiedzy/przeciwdzialanie-szarej-strefie-2/, dostęp: 14.02.2020).

48 Ibidem, s. 36.

49 Dz.U. z 2016 r., poz. 2024. 
- obowiązek składania przez większość podatników deklaracji, informacji podsumowujących (i ich korekt) dla podatku od towarów i usług wyłącznie drogą elektroniczną.

Przywrócono również tzw. sankcję podatkową za nierzetelne rozliczanie podatku VAT i radykalnie zmieniono zasady dokonywania zwrotów podatku VAT w terminie 25-dniowym. Zmiana odnosząca się do zwrotów podatku VAT w terminie 25 dni w sposób wyraźny ograniczyła ich stosowanie poprzez zwiększenie wymogów formalnych koniecznych dla otrzymania zwrotu w tym terminie. Od stycznia 2017 r. została wprowadzona możliwość nałożenia przez urząd na podatnika specjalnej kary, zwanej sankcją VAT. Warto podkreślić, że ten mechanizm znalazł się w przepisach o podatku od towarów i usług ponownie ${ }^{50}$. Mechanizm działania tego środka przewiduje, iż w przypadku zaniżenia podatku lub zawyżenia kwoty zwrotu urząd skarbowy może nałożyć na podatnika karę w wysokości 30\% kwoty niedopłaconej fiskusowi. Natomiast kara wynosi 100\% niezapłaconej kwoty, gdy wynikała z „pustych” faktur - wystawionych przez nieistniejący podmiot, potwierdzających nieistniejące transakcje lub opiewających na niezgodne z rzeczywistością kwoty. Szczególnie istotne zmiany miały miejsce w obszarze rejestracji podatników VAT, gdzie znacząco zwiększono liczbę okoliczności skutkujących wykreśleniem podatnika $\mathrm{z}$ rejestru.

W pierwszym półroczu 2017 r., tj. po wejściu w życie zmian w ustawie o podatku od towarów i usług, $\mathrm{z}$ rejestru podatników wykreślono 154300 podatników, co stanowi 79,3\% podatników wykreślonych w całym 2016 r. W trzecim kwartale 2017 r. wykreślono 61700 podatników. Na podstawie art. 96 ust. 6-8 ustawy o podatku od towarów i usług w pierwszym półroczu 2017 r. wykreślono 89000 podmiotów (co stanowi 50,7\% wykreśleń na tej podstawie w całym 2016 r.) oraz 34500 w trzecim kwartale $2017 \mathrm{r}^{51}$

501 grudnia 2008 r. usunięto z ustawy o podatku od towarów i usług przepisy przewidujące tzw. sankcję, motywując to toczącym się postępowaniem przez Trybunałem Sprawiedliwości Unii Europejskiej. Jednak Trybunał w wyroku z dnia 15 stycznia 2009 r. w sprawie polskiego podatnika K1 Sp. $z$ o.o. (C-502/07) uznał, że dodatkowe zobowiązanie podatkowe przewidziane w polskim ustawodawstwie nie ma cech podatku, lecz jest sankcją o charakterze administracyjnym, której wprowadzenie nie stoi w sprzeczności z prawem Unii Europejskiej.

${ }^{51}$ Informacja o wynikach kontroli NIK, KBF.430.003.2018, Nr ewid. 23/2018/P/17/013/ KBF, Warszawa 2018, s. 33. 
Pakiet uszczelniający modyfikował również obowiązujące już „środki uszczelniające”, takie jak mechanizm odwrotnego obciążenia, czy też instytucję solidarnej odpowiedzialności. Szczególnie tę ostatnią instytucję wyraźnie zmieniono, wprowadzając odpowiedzialność solidarną pełnomocnika dokonującego rejestracji dla potrzeb VAT w imieniu podatnika do kwoty 500 tys. zł za zaległości podatkowe podatnika powstałe z tytułu czynności wykonanych w ciągu sześciu miesięcy od dnia zarejestrowania podatnika jako podatnika VAT czynnego. Dodatkowo podwyższono kary za wystawianie i posługiwanie się fałszywymi fakturami przewidziane w Kodeksie karnym skarbowym. Ministerstwo Finansów oszacowało, że dodatkowe wpływy podatkowe w pierwszym półroczu 2017 r. z tytułu

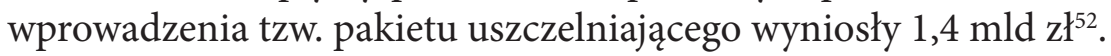

Pakiet uszczelniający został dopełniony regulacjami o charakterze prewencyjnym. Modyfikacja polityki karnej w tym zakresie wynikała z ocen dotychczasowego stosowania przepisów karnych w postępowaniach, które dotyczyły oszustw związanych z podatkiem VAT. W okresie 2014-2016, w sprawach, których przedmiotem były wyłudzenia nienależnego zwrotu podatku VAT, zapadły wyroki wobec 253 osób, z czego jedynie 31 osób skazanych zostało na kary pozbawienia wolności bez warunkowego zawieszenia ich wykonania ${ }^{53}$. Przy czym wyroki odnosiły się do nienależnych zwrotów dużej wartości w rozumieniu art. $53 \$ 15$ Kodeksu karnego skarbowego, zgodnie z którym „Duża wartość jest to wartość, która w czasie popełnienia czynu zabronionego przekracza pięćsetkrotną wysokość minimalnego wynagrodzenia" ${ }^{4}$. Sytuacje w tym zakresie miała zmienić nowelizacja Kodeksu karnego, która weszła w życie z dniem 1 marca 2017 r. ${ }^{55}$ Wprowadziła ona wiele kategorii przestępstw, takich jak wystawianie fikcyjnych faktur, ich podrabianie i przerabianie. Zagrożenie karą uzależniono od kwoty należności na dokumencie. Jako zbrodnia (tj. czyn zagrożony karą więzienia nie krótszą niż 3 lata) zostało stypizowane przestępstwo, gdy wartość towarów i usług przekracza $5 \mathrm{mln}$ zł. Natomiast za fałszowanie

52 Ibidem, s. 16.

${ }^{53}$ M. Warchoł, Odpowiedź na zapytanie nr $1181 \mathrm{w}$ sprawie rządowego projektu ustawy o zmianie ustawy - Kodeks karny oraz niektórych innych ustaw (druk sejmowy nr 888/VIII kadencja).

54 Ustawa z dnia 10 września 1999 r. Kodeks karny skarbowy (tekst jedn. Dz.U. z 2020 r., poz. 19 ze zm.).

${ }^{55}$ Ustawa z dnia 10 lutego 2017 r. o zmianie ustawy - Kodeks karny oraz niektórych innych ustaw (Dz.U z 2017 r., poz. 244). 
faktur na kwotę ponad $10 \mathrm{mln}$ zł grozi kara od 5 do 15 lat pozbawienia wolności, a w najcięższych wypadkach nawet 25 lat więzienia ${ }^{56}$. Dostępne w sferze publicznej dane wskazują na wzrost aktywności nie tylko organów skarbowych, lecz także prokuratorskich. Na przykład w odpowiedzi na interpelację nr 27039 posła Marka Biernackiego z dnia 30 października 2018 r. wskazano na wzrastającą liczbę prowadzonych przez prokuraturę krajową postępowań przygotowawczych, w których uszczuplenie lub narażenie na uszczuplenie należności publicznoprawnych $\mathrm{z}$ tytułu podatku VAT wynosi powyżej 1 mln złotych, a w szczególności na wzrastającą liczbę aktów oskarżenia (2016 r. - 128 aktów obejmujących 157 oskarżonych, w 2017 r. - 196 aktów obejmujących 581 oskarżonych, w pierwszej połowie 2018 r. - 128 aktów obejmujących 346 oskarżonych). Wskazywano również na wzrastającą $\mathrm{w}$ tej kategorii liczbę skazań na bezwzględną karę pozbawienia wolności (w 2016 r. 14 osób, w 2017 r. 38 osób, w pierwszym półroczu 2018 r. 51 osób). Zgodnie z informacjami prasowymi zarzut tzw. zbrodni VAT został postawiony przez organy prokuratorskie już $\mathrm{w}$ ponad stu sprawach od chwili wprowadzenia tych regulacji. Natomiast w odniesieniu do zagrożenia 25 lat pozbawienia wolności (gdy wartość fikcyjnych faktur przekroczy $10 \mathrm{mln}$ zł) prokuratorzy postawili w latach 2018-2019 już 37 zarzutów (15 z nich zostało objętych aktem oskarżenia) $)^{57}$. Trzeba także wspomnieć o wprowadzeniu rozwiązań, które w sposób pośredni oddziaływały na eliminację nieprawidłowości występujących w rozliczeniach podatku VAT. Najważniejszym rozwiązaniem z tego obszaru było wprowadzenie możliwości weryfikowania przez samych podatników VAT statusu ich kontrahentów. W tym celu stworzono wyszukiwarki podatników znane pod nazwami wykazów podatników VAT - tzw. czarnej, a następnie białej listy. Umożliwia ona sprawdzenie, czy dany podmiot gospodarczy jest zarejestrowanym podatnikiem VAT. Podatnicy uzyskali dostęp do informacji o statusie kontrahentów na wybrany dzień za pomocą określonego kryterium dostępu, którym może być wybrany numer NIP, nazwa, a w przypadku osób fizycznych imię i nazwisko oraz numer rachunku bankowego wykorzystywanego do prowadzenia działalności gospodarczej. Możliwość sprawdzenia kontrahenta została ograniczona do pięciu lat poprzedzających rok, w którym podatnik zada takie pytanie. Ustawodawca nie wskazał

56 J. Sarnowski, P. Selera, Zmniejszenie luki VAT w Polsce w latach 2016-2017..., s. 18.

$57 \mathrm{Juz}$ niemal sto zbrodni vatowskich. Sprawcom grozi 25 lat więzienia, https:// www.forbes.pl/prawo-i-podatki/zbrodnia-vat-owska-grozi-15-lub-nawet-25-latwiezienia/7shtdwy (dostęp: 15.02.2020). 
spodziewanych korzyści dla budżetu państwa z tytułu wprowadzenia tego rozwiązania. W Ocenie Skutków Regulacji wyrażono jedynie oczekiwanie, że proponowane rozwiązania nie wpłyną na zmniejszenie dochodów budżetu państwa. Natomiast w średnim okresie spodziewano się wzrostu dochodów budżetu państwa, które miałyby wynikać $\mathrm{z}$ wprowadzenia sankcji dla podatników, którzy płacą na inne rachunki niż zgłoszone i publikowane w wykazie podatników VAT ${ }^{58}$. Oczekiwano również pośredniego skutku w postaci „samouszczelnienia” się systemu podatku od towarów i usług. Ponadto zakładano, że dzięki wprowadzeniu możliwości dokonania weryfikacji danych kontrahenta przedsiębiorcy otrzymają narzędzie pozwalające na uniknięcie przez nabywców towarów i usług ryzyka wplątania ich w oszukańczy proceder zmierzający do wyłudzenia VAT. Tym samym, zdaniem autorów uzasadnienia do projektu ustawy, zostanie ograniczona nieuprawniona przewaga, jaką podmioty dopuszczające się oszustw podatkowych osiągały dotychczas nad uczciwymi podatnikami VAT ${ }^{59}$. W obiegu publicznym brak jest dotąd informacji, czy te wszystkie cele udało się zrealizować.

4. Rewolucja organizacyjna. NajWięKSZa ReForma ADMINISTRACJI PODATKOWEJ, SKARBOWEJ I CELNEJ PO 1989 R.

Tym szerokim działaniom legislacyjnym towarzyszyły równie ambitne przemiany organizacyjne. Z dniem 1 marca 2017 r. wprowadzono w życie nowy model administracji skarbowej - Krajową Administrację Skarbową ${ }^{60}$, który powstał z połączenia dotychczasowej administracji podatkowej, służby celnej i kontroli skarbowej. Centralizacja wszystkich struktur administracyjnych zaangażowanych w pobór należności publicznoprawnych jest największą zmianą organizacyjną administracji podatkowej, skarbowej i celnej od początku lat dziewięćdziesiątych XX w. Nieukrywanym celem tej reformy było zwiększenie efektywności wszystkich dawnych administracji przede wszystkim poprzez usprawnienie przepływu informacji pomiędzy organami kontrolnymi oraz zwiększenie skuteczności

58 Ocena skutków regulacji, druk sejmowy nr 3301/VIII kadencja, s. 6.

59 Uzasadnienie do projektu ustawy, druk sejmowy nr 3301/VIII kadencja, s. 2, 10, 21.

${ }^{60}$ Model ten został wprowadzony Ustawą z dnia 16 listopada 2016 r. o Krajowej Administracji Skarbowej (Dz.U. z 2016 r., poz. 1947 ze zm.) oraz Ustawą z dnia 16 listopada 2016 r. - Przepisy wprowadzające ustawę o Krajowej Administracji Skarbowej (Dz.U. z 2016 r., poz. 1948 ze zm.). 
w zwalczaniu szarej strefy. Temu celowi służyła głęboka integracja dawnych struktur kontroli skarbowej i służby celnej, wyraźnie skierowana na zwalczanie obszaru „ciężkich” oszustw podatkowych. Wydaje się, że reforma przyniosła rezultaty już w pierwszym roku od jej wprowadzenia. W literaturze dominuje teza, że działań kontrolnych było mniej, ale stały się bardziej efektywne. Liczba kontroli zrealizowanych przez urzędy kontroli skarbowej (od 1 marca 2017 r. urzędy celno-skarbowe) zmniejszyła się niemal o 1/5: z 5775 w 2016 r. do 4648 w 2017 r. O ile wpłaty dokonane w wyniku kontroli wyniosły w 2016 r. 2,3 mld zł, to już po trzech kwartałach 2017 r. czynności kontrolne uchroniły Skarb Państwa przed stratą 2,38 mld zł. Z kolei urzędy skarbowe przeprowadziły w 2015 r. 29260 kontroli, w wyniku których u 76,6\% podmiotów stwierdzono nieprawidłowości. W 2017 r. kontroli było o ponad 1/3 mniej, przy jednoczesnym wzroście wykrywanych nieprawidłowości do $83,3 \%{ }^{61}$. Liczba kontroli rozliczeń VAT, w których stwierdzono nieprawidłowości, zmniejszyła się z 3750 w 2016 r. do 2549 w 2017 r., tj. o 32\%, i do 1765 w 2018 r., tj. o 30,8\% w porównaniu do 2017 r. Od stycznia do września 2018 r. wyniosła 1334. Przy zmniejszającej się liczbie prowadzonych kontroli ich skuteczność mierzona relacją liczby kontroli, w których stwierdzono nieprawidłowości, do liczby przeprowadzonych kontroli wzrosła z 77,3\% w 2016 r. i 79,3\% w 2017 r. do 84,8\% w 2018 r. W okresie od stycznia do września 2018 r. relacja ta wynosiła również $84,8 \%$. Kwota nieprawidłowości stwierdzonych w wyniku kontroli rozliczeń VAT zmniejszyła się z 20 069,7 mln zł w 2016 r. do 13 040,4 mln zł w 2017 r. Tendencja spadkowa utrzymywała się w 2018 r., kiedy to w kontrolach skarbowych i celno-skarbowych stwierdzono w trzech pierwszych kwartałach nieprawidłowości na kwotę 6598 mln zł oraz w całym 2018 r. na kwotę 9276,4 mln zł. Spadek ustaleń kontrolnych przedstawiany jest jako wynik ograniczenia aktywności kontrolnej wobec niektórych podmiotów (np. slupów i znikających podatników) i wykrywania nieprawidłowości bez wszczynania kontroli, przy wykorzystaniu czynności sprawdzających ${ }^{62}$.

Warto podkreślić, że sam proces tworzenia Krajowej Administracji Skarbowej nie spowodował obniżenia efektywności jej pracy. Liczba zwrotów związanych z wadliwymi decyzjami w pierwszym półroczu

61 J. Sarnowski, P. Selera, Zmniejszenie luki VAT w Polsce w latach 2016-2017..., s. 21.

${ }^{62}$ Informacja o wynikach kontroli NIK, KBF.430.002.2019, Nr ewid. 80/2019/P/18/011/ KBF, Warszawa 2019, s. 88-89. 
2018 r. wyniosła 367 i była o 30,5\% niższa od liczby zwrotów dokonanych w pierwszej połowie 2016 r. Kwota odsetek wypłaconych w wyniku uchylenia wadliwych decyzji w pierwszej połowie 2018 r. wyniosła 40,9 mln zł i była o 22,9\% niższa od kwoty wypłaconej w pierwszym półroczu $2016 \mathrm{r}$. Wskaźnik uchylonych decyzji (obliczony jako stosunek liczby decyzji w zakresie podatków PIT, CIT i VAT uchylonych w II instancji do liczby decyzji wydanych w okresie rozliczeniowym) w pierwszym półroczu 2018 r. wyniósł 8,7\% i był o 1,2 punktu procentowego korzystniejszy (tj. niższy) niż w pierwszym półroczu 2016 r. Wskaźnik uchylonych decyzji (liczony jako stosunek liczby decyzji w zakresie PIT, CIT i VAT uchylonych w II instancji do liczby odwołań złożonych w okresie rozliczeniowym) wyniósł 28,3\% i był o 10,6 punktu procentowego korzystniejszy (tj. niższy) niż w pierwszym półroczu 2016 r. Liczba skarg wnoszonych przez podatników do wojewódzkich sądów administracyjnych utrzymała się na zbliżonym poziomie. W pierwszym półroczu 2018 r. wyniosła 11 100, a w pierwszym półroczu 2016 r. - 11 300. Udział orzeczeń wojewódzkich sądów administracyjnych korzystnych dla organów podatkowych (tj. utrzymujących w mocy decyzję lub postanowienie) w pierwszej połowie 2018 r. wyniósł $80 \%$ i był nieco niższy niż w pierwszej połowie 2016 r. (80,3\%). Poprawił się wskaźnik ściągalności należności wobec budżetu państwa (liczony jako stosunek kwoty wyegzekwowanych zaległości do kwoty zaległości objętej tytułami wykonawczymi). W pierwszym półroczu 2018 r. wyniósł on 21,9\% i był o 7,5 punktu procentowego wyższy niż w pierwszej połowie $2016 \mathrm{r}^{63}$

Powyższe dane można uznać za realizację celów przeprowadzonej reformy, której założeniem było osiągnięcie lepszych wyników pracy aparatu skarbowego jako całości. Należy jednak zwrócić uwagę na głosy krytyczne wobec utworzenia jednolitej Krajowej Administracji Skarbowej. Najbardziej kompleksowa ocena tego procesu została dokonana przez Najwyższą Izbę Kontroli w wyniku kontroli „Stan organizacji Krajowej Administracji Skarbowej"64. Wskazano w niej na dwa zasadnicze niedociągnięcia w procesie powstawania KAS. Po pierwsze, uznano, że proces kształtowania i realizacji polityki kadrowej w KAS nie został należycie przygotowany i przeprowadzony. W wyniku reformy zatrudnienie ogółem w jednostkach

${ }^{63}$ InformacjaowynikachkontroliNIK,KBF.430.012.2019,Nrewid.159/2019/P/18/009/ KBF, Warszawa 2019, s. 109.

64 Ibidem, s. 88-89. 
KAS nie uległo istotnej zmianie, a sam proces kształtowania kadr wzbudził liczne kontrowersje ${ }^{65}$. Dodatkowo nie wdrożono horyzontalnego modelu zarządzania $\mathrm{w}$ zakresie IT. Pomimo prowadzenia prac w celu utrzymania ciągłości działania użytkowanych systemów informatycznych oraz ich rozwoju nie podjęto skutecznych działań w celu sprawnego wdrożenia części systemów informatycznych niezbędnych do usprawnienia funkcjonowania jednostek organizacyjnych $\mathrm{KAS}^{66}$.

5. W POSZUKIWANIU NOWEGO OBSZARU AKTYWNOŚCI Krajowa Administracja Skarbowa a instytucje finansowe

Szerokie zmiany legislacyjne oraz organizacyjne, które miały miejsce w roku 2017, nie zakończyły aktywności legislacyjnej Ministerstwa Finansów w obszarze uszczelniania podatku VAT, ale rozmach już zrealizowanych zmian wyraźnie zepchnął w cień kolejne inicjatywy legislacyjne Ministerstwa Finansów. Przy czym można je uznać za pionierskie nie tylko z perspektywy krajowej.

Niezwykle interesującą i chyba rozpoznawalną medialnie propozycją „uszczelniania” systemu VAT jest mechanizm podzielonej płatności (split payment). Zaczął on obowiązywać w systemie podatku od towarów i usług $\mathrm{z}$ dniem 1 lipca $2018 \mathrm{r}$ jako rozwiązanie dobrowolne. Istotą split payment jest podzielenie przez nabywcę kwoty należnej dostawcy towarów na dwie części:

- kwotę stanowiącą wynagrodzenie dostawcy,

- kwotę należnego podatku wynikającego z tej dostawy.

Właśnie ta druga część zostaje wpłacona na specjalnie wyodrębnione konto bankowe nabywcy. Podzielona płatność jest więc rozwiązaniem o charakterze technicznym niewpływającym na inne instytucje podatku od towarów i usług. Jej oczywistym celem jest poddanie szczególnej kontroli tej części kwoty, która odpowiada kwocie należnego podatku VAT. Odbiorcy płatności formalnie pozostają właścicielami środków znajdujących się na rachunkach VAT, ale ich faktyczne władztwo nad tymi środkami ulega poważnym ograniczeniom. Formalny właściciel rachunku ma całkowitą swobodę dysponowania zgromadzonymi na nim środkami jedynie w zakresie

${ }^{65}$ Informacja o wynikach kontroli NIK, KBF.430.002.2019, Nr ewid. 80/2019/P/18/011/ KBF, Warszawa 2019, s. 41.

66 Ibidem, s. 21. 
płatności dokonywanych na rzecz budżetu państwa. Przekazanie środków na „Zwykły” rachunek rozliczeniowy podatnika może nastąpić wyłącznie pod kontrolą organów podatkowych. Jak widać, split payment ma istotny wpływ na proces rozliczania podatku VAT przez podmioty gospodarcze. Wydaje się, że największą wadą mechanizmu podzielonej płatności, z punktu widzenia prowadzących działalność gospodarczą, jest ograniczenie możliwości wykorzystania pieniędzy, które znajdują się na rachunku VAT. Pieniądze $\mathrm{z}$ tego rachunku mogą być zasadniczo wydatkowane tylko na zapłatę VAT do urzędu skarbowego bądź zapłatę VAT wynikającego z faktur zakupowych. Ustawodawca, mając świadomość niekorzystnego wpływu tego rozwiązania na parametr płynności przedsiębiorstwa, wprowadził wiele istotnych zachęt do korzystania z podzielonej płatności, takich jak:

- uznanie korzystania z podzielonej płatności za istotną przesłankę dochowania należytej staranności, brak odpowiedzialności solidarnej i dodatkowego zobowiązania podatkowego;

- wyłączenie stosowania 150\% stawki odsetek za zwłokę;

- obniżenie kwoty zobowiązania (tzw. skonto);

- zwrot różnicy podatku w przyspieszonym terminie 25 dni.

Ustawodawca niemal natychmiast podjął prace nad wprowadzeniem obligatoryjnego mechanizmu podzielonej płatności. W maju 2018 r. Polska wystąpiła do Komisji Europejskiej z wnioskiem o możliwość objęcia obowiązkowym mechanizmem podzielonej płatności towarów i usług z tzw. branż wrażliwych, w których stwierdzono występowanie oszustw w podatku VAT. Zgoda na stosowanie przez Polskę tego mechanizmu jest drugim takim przypadkiem we wspólnocie (po Włoszech) ${ }^{67}$. Na podstawie uzyskanej derogacji z dniem 1 listopada 2019 r. stosowanie podzielonej płatności stało się obowiązkowe w odniesieniu do sprzedaży usług i towarów wymienionych w załączniku nr 15 do ustawy o VAT w sytuacji, gdy wartość brutto transakcji wyniesie powyżej 15000 zł lub równowartość tej kwoty ${ }^{68}$. Jednocześnie zastąpiła ona mechanizm odwrotnego obciążenia oraz kaucji gwarancyjnej przy solidarnej odpowiedzialności.

${ }^{67}$ Wniosek - decyzja wykonawcza Rady w sprawie upoważnienia Polski do wprowadzenia szczególnego środka stanowiącego odstępstwo od art. 226 dyrektywy 2006/112/ WE w sprawie wspólnego systemu podatku od wartości dodanej, Bruksela, COM(2019) 10 final 2019/0007(NLE) z dnia 23 stycznia 2019 r., s. 3.

${ }^{68}$ Ustawa z dnia 9 sierpnia 2019 r. o zmianie ustawy o VAT oraz niektórych innych ustaw (Dz.U. z 2019 r., poz. 1751). 
Ustawodawca nie ukrywał swoich intencji związanych z wprowadzeniem podzielonej płatności do podatku od towarów i usług. W ocenie skutków regulacji projektu ustawy wskazano, „że szacowane obecnie ubytki dochodów z tytułu oszustw w podatku VAT na kwotę $10 \mathrm{mld}$ zł zostaną ograniczone w stosunku do stanu obecnego: w 2018 r. o 30\%, w 2019 r. o 75\%, w 2020 r. o $80 \%$, w 2021 r. o $85 \%$, w 2022 r. o $90 \% " 69$. Obecnie w obiegu publicznym brak szacunków, czy cel wskazany na rok 2018 został zrealizowany. Dostępne dane wskazują jedynie na rosnącą popularność tego mechanizmu. Według danych Ministerstwa Finansów do końca roku do zapłaty w mechanizmie podzielonej płatności wykorzystano ok. 400000 rachunków, w drugim półroczu 2018 r. podatnicy przeprowadzili 7,4 mln transakcji z zastosowaniem mechanizmu podzielonej płatności, a kwota podatku przekazana na specjalne rachunki do rozliczeń VAT wyniosła ok. 26 mld zł. Wartość podatku płaconego z zastosowaniem tego mechanizmu w lipcu 2018 r. wyniosła 2,4 mld zł, a w grudniu 2018 r. $-6,7$ mld $z^{70}$. Natomiast w roku 2019 podatnicy w ramach split payment dokonali 27,4 mln transakcji. Wysokość obrotów dokonywanych na rachunkach tego typu osiągnęła $463 \mathrm{mld}$ zł, a wartość podatku VAT - 95,7 mld zł¹.

Podobnym do podzielonej płatności rozwiązaniem wydaje się tzw. mechanizm STIR (akronim od System Informatyczny Krajowej Izby Rozliczeniowej), który również koncentruje się na środkach pieniężnych. Jest on przeniesieniem na grunt Ordynacji podatkowej rozwiązań wypracowanych w obszarze prawa bankowego i regulacjach mających na celu przeciwdziałanie praniu pieniędzy, finansowaniu terroryzmu, czy też wykorzystaniu systemu bankowego (SKOK-ów) do działalności przestępczej w zakresie przestępstw skarbowych ${ }^{72}$. W ten sposób wprowadzono do systemu prawa podatkowego powstałą na gruncie prawa bankowego instytucję izby rozliczeniowej (Krajowej Izby Rozliczeniowej na gruncie Ordynacji podatkowej), organizującej współpracę pomiędzy instytucjami finansowymi ${ }^{73}$.

${ }^{69}$ Druk sejmowy nr 1864/VIII kadencja.

${ }^{70}$ Informacja o wynikach kontroli NIK, KBF.430.002.2019, Nr ewid. 80/2019/P/18/011/ KBF, Warszawa 2019, s. 61.

71 Liczba transakcji split payment zbliżyła się $w$ grudniu do $6 \mathrm{mln}$ operacji, https:// podatki.gazetaprawna.pl/artykuly/1449386,split-payment-obowiazkowy-krajowa-izba-rozliczeniowa-statystyki.html (dostęp: 15.02.2020).

72 Artykuł 106a ustawy Prawo bankowe (tekst jedn. Dz.U. z 2018 r., poz. 2187) oraz art. 16 Ustawy o spółdzielczych kasach oszczędnościowo-kredytowych (tekst jedn. Dz.U. z 2018 r., poz. 2386).

73 Artykuł 67 ustawy Prawo bankowe (tekst jedn. Dz.U. z 2019 r., poz. 2357). 
Drugim implementowanym na grunt prawa podatkowego rozwiązaniem jest uprawnienie instytucji finansowej (banku czy spółdzielczej kasy oszczędnościowej) do tymczasowego zablokowania środków na prowadzonym przez niego rachunku bankowym na okres nieprzekraczający 72 godzin w przypadku uzasadnionego podejrzenia, że zgromadzone na nim środki pochodzą z przestępstwa lub mają związek z przestępstwem innym niż pranie pieniędzy lub finansowanie terroryzmu. W regulacjach prawa bankowego o zastosowaniu blokady niezwłocznie zostaje poinformowany właściwy prokurator, który, jeśli postanowi o wszczęciu postępowania, może wstrzymać określoną transakcję lub dokonać blokady środków na rachunku maksymalnie na okres 3 miesięcy, licząc od dnia otrzymania zawiadomienia banku o dokonaniu tymczasowej blokady ${ }^{74}$. W systemie STIR domniemanie o charakterze środków zgromadzonych na rachunku, które uprawnia do stosowania blokady, powstaje na podstawie tzw. wskaźnika ryzyka wykorzystywania działalności banków i spółdzielczych kas oszczędnościowo-kredytowych do celów mających związek z wyłudzeniami skarbowymi, wypracowany przez Krajową Izbę Rozliczeniową. Organ Krajowej Administracji Skarbowej, czyli Szef KAS, może dokonać blokady zasadniczo na okres nie dłuższy niż 72 godziny. Możliwe jest przedłużenie blokady w uzasadnionych przypadkach na okres nie dłuższy niż 3 miesiące. W toku kolejnych nowelizacji ustawodawca nadał 72-godzinnej blokadzie charakter kwalifikowany, gdyż wyeliminował możliwość zaskarżania dokonywanych blokad rachunku, a dodatkowo „Bank oraz spółdzielcza kasa oszczędnościowo-kredytowa nie ujawniają podmiotowi kwalifikowanemu informacji o przekazaniu żądania lub dokonaniu blokady rachunku podmiotu kwalifikowanego na żądanie Szefa KAS na okres do 72 godzin"75. W przeciwieństwie do blokady na okres 72 godzin postanowienie o przedłużeniu terminu blokady na okres do 3 miesięcy podlega kontroli w trybie odwoławczym. Nie zmienia to faktu, że blokada rachunków bankowych jest niezwykle silnym środkiem o charakterze administracyjnym, który może

74 Artykuł 106a ust. 3-7 Ustawy Prawo bankowe (tekst jedn. Dz.U. z 2019 r., poz. 2357).

75 Artykuł 119zv $\$$ 4a Ustawy z dnia 29 sierpnia 1997 r. Ordynacja podatkowa (tekst jedn. Dz.U. z 2019 r., poz. 900).W uzasadnieniu projektu wskazano, że takie rozwiązanie zostało wprowadzone „ze względu na prewencyjny charakter blokady oraz konieczność zachowania poufności systemu działań operacyjnych namierzających przestępstwa oraz krótki czas trwania blokady" (Uzasadnienie do rządowego projektu ustawy o zmianie ustawy - Ordynacja podatkowa oraz niektórych innych ustaw, druk sejmowy nr 2626/ VIII kadencja). 
budzić wątpliwości. Bezspornie ingeruje ona w legislacyjnie chronione wartości związane ze swobodą dysponowania majątkiem, w tym w umowne zobowiązania pomiędzy bankiem a posiadaczem rachunku. Ten dysonans zapewne zostanie rozstrzygnięty w przyszłości przez judykaturę.

Trzeba podkreślić, że Ministerstwo Finansów wiązało z wprowadzeniem systemu STIR duże nadzieje. W Ocenie Skutków Regulacji określono oczekiwane wpływy podatkowe w 2018 r. na ok. $2,5 \mathrm{mld} \mathrm{zł}^{76}$. Spodziewano się, że liczba blokad rachunku na okres nie dłuższy niż 72 godziny w pierwszym roku funkcjonowania nowego systemu wyniesie ok. 700 blokad rocznie. W kolejnych latach ta liczba powinna ulec znacznemu zmniejszeniu. W zakresie blokad rachunku wynikających z postanowienia o przedłużeniu terminu blokady rachunku bankowego zakładano, że odsetek przedłużanych blokad będzie mniejszy niż blokad na okres 72 godziny i wyniesie ok. 630 blokad rocznie ${ }^{77}$. Informacje prasowe donoszą o wpływach w wysokości 3 mln złotych i blokadzie 72 rachunków ${ }^{78}$.

$\mathrm{Z}$ informacji na stronie internetowej Ministerstwa Finansów wynika natomiast, że automatyczne procesy ustalania wskaźnika ryzyka wskazały ok. 26000 podmiotów wysokiego i podwyższonego ryzyka wykorzystania sektora finansowego do wyłudzeń skarbowych. Informacje STIR, w tym dane przeszło 5 mld transakcji finansowych, zostały wykorzystane w budowanych przez KAS nowoczesnych rozwiązaniach analitycznych. Pozwala to na szybką i efektywną identyfikację podmiotów uczestniczących w wyłudzeniach skarbowych. Przewidziana przez ustawę STIR blokada rachunku podmiotu kwalifikowanego zapobiega transferom środków pochodzących z wyłudzeń.

Zgodnie z dostępnymi danymi na podstawie systemu STIR w 2019 r. prowadzono analizy ryzyka wykorzystywania działalności 620 banków i spółdzielczych kas oszczędnościowo-kredytowych (619 w 2018 r.) do celów mających związek z wyłudzeniami skarbowymi, opierając się na wskaźniku ryzyka oraz informacjach i zestawieniach otrzymanych z Krajowej Izby Rozliczeniowej. W 2019 r., według stanu na dzień 13 grudnia 2019 r., zasoby informacyjne STIR przetwarzane w procesach analitycznych obejmowały 11319,7 mln transakcji na 15,1 mln rachunków. W 2018 r. było

${ }^{76}$ Druk sejmowy nr 1880/VIII kadencja, s. 7.

77 Ibidem, s. 8.

${ }_{78} 26$ tys. podatników pod lupa skarbówki. Tak algorytm fiskusa wyłapuje podejrzane transakcje, https://gospodarka.dziennik.pl/podatki/artykuly/581817,podatki-podatnik-algo rytm-skarbowka-fiskus-stir-wyludzenia.html (dostęp: 14.04.2019). 
to odpowiednio 8525,1 mln transakcji na 11,6 mln rachunków. W 2019 r. ustalono 58000 podmiotów z najwyższą kategorią ryzyka wykorzystywania sektora finansowego do wyłudzeń skarbowych, a 29000 w 2018 r. Rosła liczba zablokowanych rachunków bankowych oraz kwoty środków zabezpieczonych na zablokowanych rachunkach. W okresie lipiec-grudzień 2018 r. zablokowano 10,3 mln zł na 41 rachunkach bankowych. Rachunki należały do 23 podmiotów. W pierwszym półroczu 2019 r. liczba zablokowanych rachunków bankowych wzrosła ponad pięć razy, a kwota zabezpieczona na tych rachunkach prawie trzy razy. W tym okresie zabezpieczono 26,6 mln zł na 212 rachunkach należących do 43 podmiotów. Od lipca do września 2019 r. zablokowano kolejne 13,7 mln zł na 147 rachunkach należących do 36 podmiotów kwalifikowanych. We wszystkich 102 podmiotach, których rachunki zablokowano (i zabezpieczono na nich kwotę $52 \mathrm{mln}$ zł), wszczęto, w związku z podejrzeniem uszczupleń podatkowych (oszacowanych na kwotę 306,1 mln zł), kontrole. W rezultacie zakończenia (według danych na dzień 13 grudnia 2019 r.) siedmiu postępowań podatkowych, przeprowadzonych po kontrolach, wydano decyzje w sprawie uszczupleń podatkowych na kwotę 99,1 $\mathrm{mln} \mathrm{zt}^{79}$.

\section{Podsumowanie. Próba oceny efektywności PODEJMOWANYCH DZIAŁAŃ}

Czy opisane powyżej działania legislacyjne oraz niemały wysiłek organizacyjny odniosły zamierzony skutek? Odpowiedź na to pytanie jest wbrew pozorom trudna. Za bezsporną natomiast można uznać diagnozę punktu wyjścia. Według raportów Komisji Europejskiej między latami 2006 a 2011 polska luka VAT gwałtownie wzrosła, z 0,4\% do 1,5\% PKB. W roku 2012 odnotowano największą kwotowo wartość luki (43,1 mld zł), w 2016 r. zaś spadek do 34,9 mld zł (CASE 2016; 2017; 2018) ${ }^{80}$. Polska należała do grupy państw członkowskich UE, w których luka w VAT utrzymywała się w ostatnich latach na wysokim poziomie. Według kolejnego raportu Komisji Europejskiej w 2015 r. luka w VAT osiągnęła poziom $24,51 \%$ i pomimo obniżenia się w stosunku do 2014 r. $(24,89 \%)$ i 2013 r. (26,36\%) sytuowała Polskę w grupie państw członkowskich Unii

${ }^{79}$ Informacja o wynikach kontroli NIK, KBF.410.006.01.2019, P/19/011, Warszawa 2020, s. 8.

${ }^{80}$ J. Sarnowski, P. Selera, Zmniejszenie luki VAT w Polsce w latach 2016-2017..., s. 11. 
Europejskiej z najwyższymi wartościami tego wskaźnika ${ }^{81}$. Szacunki te są zbieżne z szacunkami Ministerstwa Finansów, przedstawionymi w Wieloletnim Planie Finansowym Państwa na lata 2017-2020, przyjętym 25 kwietnia 2017 r. przez Radę Ministrów - luka podatkowa w 2016 r. wyniosła 21,9\%, podczas gdy w 2015 r. - 23,5\%, a w latach 2012-2013 - ponad 25\%. Uzyskanie o blisko 1/4 wyższych dochodów w 2017 r. niż w roku poprzednim uznano za przejaw dalszego obniżenia się poziomu luki podatkowej w VAT ${ }^{82}$. Zgodnie z przyjętymi przez Ministra Rozwoju i Finansów w lipcu 2017 r. założeniami, do 2020 r. Polska w wyniku poprawy ściągalności należności podatkowych powinna zredukować lukę VAT do przeciętnego poziomu, jaki osiągają kraje Unii Europejskiej, tj. do $10,4 \%^{83}$.

Choć te statystki wykazują różne dane, to wzrost wpływów z podatku VAT po roku 2015 jest faktem. Zasadniczym problemem jest wszakże jednoznaczny związek przyczynowo-skutkowy pomiędzy konkretnymi działaniami mającymi na celu tzw. uszczelnienie podatku VAT a rzeczywistymi kwotami wpływającymi do budżetu. Pierwszym problemem jest określenie punktu odniesienia, czyli rozmiaru samej luki podatkowej. Szacunki każdej metodologii są niedokładne. W przypadku dominującej metodologii "góra-dół”, czyli opartej na danych makroekonomicznych, zasadniczy problem wynika z szacunkowego charakteru danych statystycznych, które są podstawą do szacowania w tej metodologii. Metoda ta wydaje się zawyżać wielkość luki podatkowej ${ }^{84}$. Natomiast metoda „dół-góra”, bazująca na danych mikroekonomicznych (np. na dokumentacji procesowej prowadzonych postępowań), może nie być reprezentatywna dla całej populacji podatników. Stosowanie metod statystycznych (np. wyniki losowo

${ }^{81}$ Study and Reports on the Vat Gap in the EU-28 Member States: 2017 Final Report. TAXUD/2015/CC/131, wrzesień 2017.

${ }^{82}$ Rada Polityki Pieniężnej w opinii do projektu Ustawy budżetowej na rok 2018 (z 7 listopada 2017 r., s. 4) wskazała, że zgodnie z szacunkami publikowanymi przez Komisję Europejską, w okresie po światowym kryzysie gospodarczym, tj. w latach 2010-2015, luka VAT wynosiła przeciętnie 24\%, podczas gdy średnio w UE było to $17 \%$. Według przybliżonych rachunków NBP w latach 2016-2017 luka VAT w Polsce uległa zmniejszeniu łącznie o ponad 9 punktów procentowych.

${ }^{83}$ Zarządzenie Ministra Rozwoju i Finansów z dnia 25 lipca 2017 r. w sprawie kierunków działania i rozwoju Krajowej Administracji Skarbowej na lata 2017-2020 (Dz.Urz. MRiF z 2017 r., poz. 144).

${ }^{84}$ Ucieczka przed podatkami i kontrola podatkowa, red. H. Kuzińska, Warszawa 2018, s. 96. 
prowadzonych kontroli wszczynanych bez analizy ryzyka) nie wystarcza do zapewnienia obiektywności prowadzonych szacunków. Można jednak zaproponować uproszczone, lecz dość pewne podejście do takich obliczeń, w których wartość globalnej luki podatkowej pozostawia się ośrodkom naukowym. Oblicza się tylko wartość luki pewnej - minimalnej, rozumianej jako wielkość wpływów podatkowych odniesionych do PKB lub - jak w przypadku VAT - do wartości dodanej, która powinna zostać osiągnięta, gdyby stosowano przepisy prawa i metody administrowania systemem podatkowym z roku, w którym nie było zmian stawek podatkowych i w którym osiągnięto najwyższą wydajność tych danin. Innymi słowy, skoro już wcześniej osiągnęliśmy lepsze rezultaty w poborze podatków, należy sprawdzić, co zostało później zepsute, że ten pobór, pomimo niezmienianych stawek, pogorszył się. Nie można w takim przypadku przerzucać winy za niższe wpływy podatkowe na koniunkturę gospodarczą, gdyż osiągnięty PKB (mianownik ilorazu) jest zawsze rezultatem danej koniunktury ${ }^{85}$.

Można więc powiedzieć, że od 2007 do 2016 r. utracono dochody z VAT w wysokości co najmniej 156 mld zł i chociaż nominalnie dochody z VAT w latach 2015-2016 wyraźnie wzrosły w porównaniu z rokiem 2014, to są o 26 i 27 mld zł za niskie w stosunku do potencjału podatkowego tkwiącego w owych latach w gospodarce ${ }^{86}$.

Jeśli nawet przyjąć kompromis co do oceny wielkości samego ubytku podatkowego, czyli rozmiaru luki podatkowej, to odnosząc się do samego przychodu podatkowego, ocena, czy mamy do czynienia $\mathrm{z}$ „dodatkowym” wpływem podatkowym, jest bardzo trudna. Wydaje się, że w dyskusjach o charakterze publicystycznym często mylone są dwa pojęcia:

- wzrost dochodów z tytułu podatku oraz

- zmniejszenie luki podatkowej.

Powszechnie przyjęty model luki podatkowej zakłada, że luka VAT jest różnicą pomiędzy rzeczywistymi wpływami z tytułu tego podatku a teoretyczną wartością zobowiązań podatkowych ${ }^{87}$. Wynika ona $\mathrm{z}$ obowiązujących regulacji podatkowych (wysokości stawek podatkowych, ulg, zwolnień) oraz bieżącej kondycji gospodarki (tempo wzrostu PKB, poziom sprzedaży). Informacje o wzroście dochodów budżetu zwykle nie odnoszą się do informacji o potencjalnych dochodach z VAT wynikających

\footnotetext{
${ }^{85}$ Ibidem.

${ }^{86}$ Ibidem, s. 100.

87 VTTL - VAT total theoretical liability.
} 
z poprawy sytuacji gospodarczej kraju, które w nie mniejszym stopniu wpływają na lukę VAT niż rzeczywiste wpływy podatkowe. Innymi słowy, identyfikacja wzrostu wpływów podatkowych (z podatku VAT) jako wyniku konkretnych działań jest obiektywnie trudna. Nie mogą więc dziwić rozbieżne szacunki nawet samej luki podatkowej. Na przykład według oceny przedstawionej przez bank Crédit Agricole (2018) uszczelnienie systemu podatkowego w 2017 r. przyniosło wzrost dochodów budżetowych w wysokości ok. 12,5 mld zł. Z kolei Ministerstwo Finansów szacuje, że w 2016 r. udało się odzyskać 6,6 mld zł, a w 2017 r. - 10,8 mld zł, w 2018 r. planuje się zaś odzyskać 7,7 mld zł. Daje to łącznie ok. 25 mld zł w latach 2016-2018 ${ }^{88}$. Inne oceny wskazują, że uszczelnienie systemu podatkowego przyniosło budżetowi dodatkowo ok. 10-15 mld zł rocznie ${ }^{89}$.

Niewątpliwy sukces fiskalny polegający na wzroście wpływów z podatku VAT bardzo często przysłania koszty tego sukcesu. Nie może to dziwić w debacie publicznej, z natury mającej charakter publicystyczny, przez co koncentrującej się na wyraźnych symbolach, takich jak wysokość stawek podatkowych czy kwot wpływających do budżetu państwa. Niestety, również $\mathrm{w}$ debacie profesjonalnej, $\mathrm{z}$ natury bardziej technicznej, można odnaleźć nadmierne uproszczenie oceny skutków działań „uszczelniających” system podatkowy. Zadziwiające wydaje się pomijanie tzw. obciążenia administracyjnego związanego z koniecznością wypełniania obowiązków podatkowych, które mogą stanowić istotny problem szczególnie dla mniejszych rozmiarów działalności gospodarczych. Odmiennie niż w przypadku stawek podatkowych rozmiar tego obciążenia jest trudno mierzalny. Trudno go także porównać pomiędzy poszczególnymi jurysdykcjami podatkowymi, operującymi nieraz na podstawie bardzo podobnych regulacji podatkowych. Jedną z nielicznych powszechnie uznawanych metodologii w tym zakresie jest metodologia opracowana przez Bank Światowy, znana jako miernik swobody działalności gospodarczej. Na jej podstawie opracowywany jest coroczny raport zwany „Doing Business”, który obejmuje faktycznie wszystkie gospodarki na świecie. Wyższa pozycja w rankingu wskazuje lepsze, zazwyczaj prostsze, przepisy regulujące sprawy związane $\mathrm{z}$ prowadzeniem przedsiębiorstwa oraz silniejszą ochronę własności przez prawo. „Doing Business” zawiera szczególnie interesujące opracowanie, będące autonomicznym raportem odnoszącym się wyłącznie do

${ }^{88}$ J. Sarnowski, P. Selera, Zmniejszenie luki VAT w Polsce w latach 2016-2017..., s. 31.

89 I. Morawski, Trzy lata rządów PiS w polskiej gospodarce, Warszawa 2019, s. 3. 
podatków. Chodzi tutaj o raport „Paying Taxes”. Jest on przygotowywany przez Bank Światowy we współpracy z firmą doradczą PricewaterhouseCoopers (PwC). Podstawą opracowania jest wskaźnik paying taxes, ale jego zasadniczą treścią są analizy i komentarze Banku Światowego oraz PwC. Specyfiką tej analizy jest skupienie się na pomiarze obciążenia administracyjnego podmiotów średniej wielkości związanego ze składaniem deklaracji i płaceniem podatków, a także procedurami, które odbywają się po złożeniu deklaracji. Niestety, pomiar jest dokonywany w odniesieniu do autonomicznej definicji obciążeń podatkowych. Jej zakresem są objęte wszystkie zobowiązania podatkowe bez względu na formalną klasyfikację, ale mające wpływ na sprawozdania finansowe jednostki. Jest to więc ujęcie wykraczające poza rutynowe definicje podatków. W konsekwencji właśnie kombinacja tych dwóch analiz, jak się wydaje, jest, z braku ich krajowych odpowiedników, najlepszym narzędziem do pomiaru kosztów administracyjnych działań mających na celu „uszczelnienie” podatku od towarów i usług. „Ranking” Polski w tych dwóch zestawieniach wykazuje bardzo ciekawą ewolucję. W ogólnym rankingu raportu „Doing Business” Polska zajmowała następujące miejsca: w 2019 r. - 33..$^{90}$, w 2018 r. - 27., w 2017 r. - 24., 2016 r. - 25., w 2015 r. - 32. ${ }^{91}$ Natomiast ranking „Paying Taxes" w roku 2015 daje Polsce 87. miejsce w ogólnym zestawieniu ${ }^{92}$. Całkowity czas konieczny do wywiązania się ze zobowiązań podatkowych (total tax time) określono na 286 godzin $^{93}$. W roku 2016 Polska awansowała na 58. miejsce, a czas konieczny do wywiązania się ze zobowiązań podatkowych spadł do 271 godzin $^{94}$, co oznaczało spadek o 17 godzin w stosunku do poprzedniego roku. Za podstawową przyczynę tego spadku uznano wprowadzenie elektronicznej formy składania deklaracji VAT. W treści raportu wskazano wyraźnie, że system został wprowadzony już w 2012 r., ale dopiero w roku 2014 został implementowany przez większość podatników VAT. W roku 2017 wyniki Polski były wyraźnie gorsze, choć

90 Doing business 2019, International Bank for Reconstruction and Development / The World Bank, Washington DC 2019, tabela Ease of doing business rank, s. 197.

91 Doing business 2016, International Bank for Reconstruction and Development / The World Bank, Washington DC 2016, tabela Ease of doing business rank, s. 4.

92 Paying Taxes 2015 PWC, The World Bank and International Finance Corporation, Washington 2015, tabela A3.1: Overall Paying Taxes ranking Paying Taxes 2015, s. 154.

93 Paying Taxes 2016 PWC, The World Bank and International Finance Corporation, Washington 2016, tabela A3.3: Time to comply Paying Taxes 2015, s. 161.

94 Paying Taxes 2016 PWC, The World Bank and International Finance Corporation, Washington 2016, tabela A3.1: Overall Paying Taxes ranking, s. 132. 
czas konieczny do spełnienia obowiązków podatkowych został ponownie określony na 271 godzin $^{95}$. Natomiast ogólna pozycja, na której sklasyfikowano Polskę, to 62., a w nowej metodyce oceny (tzw. post filling index) 47. miejsce w rankingu ${ }^{96}$. W roku 2018 Polskę sklasyfikowano na 51. miejscu, przy jednoczesnym określeniu godzin potrzebnych do wypełnienia obowiązków sprawozdawczych na $260^{97}$. W raporcie za rok 2019 Polska została sklasyfikowana na 69. miejscu ${ }^{98}$. Czas na wypełnienie zobowiązań podatkowych wzrósł w istotny sposób, bo aż do 334 godzin ${ }^{99}$. Przyczyny takiego wzrostu zostały szczegółowo opisane w treści raportu, a są nimi rozwiązania przyjęte $\mathrm{w}$ mechanizmie jednolitych plików kontrolnych. Jak wskazano, w Polsce wywiązywanie się ze zobowiązań podatkowych stało się bardziej skomplikowane w wyniku wprowadzenia konieczności comiesięcznego raportowania o podatku od towarów i usług, zwiększenia zakresu dóbr i usług będących przedmiotem tzw. odwróconego obciążenia oraz obowiązku składania jednolitych plików kontrolnych (SAF-T files), analogicznych do tych wprowadzonych w Hiszpanii ${ }^{100}$. W przypadku Hiszpanii nowy system raportowania skrócił czas konieczny do wypełnienia obowiązków podatkowych związanych z rozliczeniem podatku VAT o 4,5 godziny - do 30,5 godziny. W przypadku Polski analogiczny czas potrzebny na rozliczenie podatku VAT wzrósł o 76 godzin - do 172 godzin. Tak różne oddziaływanie podobnych rozwiązań jest tłumaczone stopniem zaawansowania systemów. Rozwiązania hiszpańskie są wysoce zautomatyzowane w przeciwieństwie do rozwiązań polskich. Bez wątpienia, polskie rozwiązania są łatwiejsze do implementacji ${ }^{101}$.

95 Paying Taxes 2017 PWC, The World Bank and International Finance Corporation, Washington 2017, tabela 11: Time to comply, s. 134.

96 Paying Taxes 2017 PWC, The World Bank and International Finance Corporation, Washington 2017, tabela 9: Overall Paying Taxes ranking, s. 127.

97 Paying Taxes 2018 PWC, The World Bank and International Finance Corporation, Washington 2018, tabela 1: Overall Paying Taxes ranking, s. 87; Doing biznes COUNTRY TABLES, s. 186.

98 Paying Taxes 2019, http://www.doingbusiness.org/en/data/exploretopics/paying -taxes (dostęp: 14.04.2019).

99 Doing business 2019, International Bank for Reconstruction and Development / The World Bank, Washington 2019, Country Tables, s. 197.

100 Doing business 2019, International Bank for Reconstruction and Development / The World Bank, Washington 2019, s. 146.

101 Paying Taxes 2019 PWC, The World Bank and International Finance Corporation, Washington 2019, s. 16. 
Kolejnym miernikiem jest przygotowywany przez Heritage Foundation i publikowany przez „The Wall Street Journal” wskaźnik wolności gospodarczej, powszechniej znany pod akronimem IEF (od ang. Index of Economic Freedom). Indeks ten mierzy cztery aspekty polityki gospodarczej i otoczenia regulacyjnego działalności gospodarczej: praworządność, wielkość sektora publicznego, efektywność regulacyjną (skuteczność działań regulacyjnych) i otwartość rynku. Ciężar podatkowy jest kompleksowym miernikiem opartym na kilku elementach składowych. Zawiera w sobie odniesienie do tzw. krańcowych stawek podatkowych podatków dochodowych: korporacyjnego (obciążającego działalność gospodarczą) i od dochodów osobistych, oraz do przeciętnego poziomu obciążenia podatkowego (wszelkich tytułów podatkowych nakładanych przez wszystkie szczeble administracji, zarówno rządowej, jak i samorządowej), jako procentowy udział w produkcie krajowym brutto. Na najbardziej ogólnym poziomie syntetyczny wskaźnik jest sumą trzech innych zmiennych dla każdego z badanych krajów: najwyższej efektywnej stopy podatkowej od podatku od dochodów osobistych, najwyższej efektywnej stawki podatkowej w podatku od osób prawnych oraz obciążenia podatkowego jako wskaźnika procentowego w Produkcie Krajowym Brutto. Każdy z tych elementów jest uznawany za jednakowo istotny dla ustalenia ostatecznego poziomu obciążenia podatkowego. Poziom efektywnych stawek podatku podlega jednak pewnej obróbce matematycznej, tak aby można je było odnieść do skali od 0 do 100 . Warto zauważyć, że taka konstrukcja owego parametru powoduje, iż nawet uzyskanie $0 \mathrm{z}$ jednego z branych pod uwagę wskaźników daje możliwość, na podstawie innych, uzyskania całkiem przyzwoitego wyniku ogólnego. Wskaźnik ten jest więc wyraźnie uproszczony w stosunku do metodologii „Doing Business”.

Odczyty dotyczące Polski w tym rankingu wydają się wykazywać podobne prawidłowości. W szczególności w samym wskaźniku wolności gospodarczej Polska w latach 2015-2019 wykazuje tendencję spadkową. W roku 2015 Polska zajmowała 42. pozycję z wynikiem 68,6\% (umiarkowanie wolny). W roku 2016 - 39. lokatę z wynikiem 69,3\%, w 2017 r. pozycję 45. - wynik 68,3\%. W roku 2018 Polska powtórzyła 45. lokatę z wynikiem 68,5\%. W roku 2019 Polskę sklasyfikowano z wynikiem 67,8\%, co dalej dawało kategorię umiarkowanie wolnego, ale pozycję 46. w rankingu. Sumarycznie wskaźnik Polski pogorszył się o 0,7 pkt. Spadek wynika w głównej mierze z pogorszenia skuteczności sądów $(-12,6)$, polityki monetarnej $(-2,9)$, warunków dla biznesu $(-1,8)$ i w zakresie obciążeń podatkowych $(-1,0)$. 
W rankingu zwrócono uwagę na nadmierne w ocenie jego autorów obciążenia wynikające ze struktury systemu podatkowego oraz niewydolność wymiaru sprawiedliwości ${ }^{102}$.

Nie można mieć wątpliwości, że intensywne działania podejmowane szczególnie po roku 2015 zaowocowały - unikatowymi co do zakresu i głębokości zmian legislacyjnych w krajowym systemie - zmianami w podatku od towarów i usług. Wzrost wpływów podatkowych jest bezsprzecznym faktem. Sukces fiskalny tych działań wydaje się niezaprzeczalny, ale obserwowalne są także koszty tych działań. W tym zakresie miarodajne wydają się klasyfikacje opracowywane przez instytucje międzynarodowe. Mimo ich niedoskonałości, przejawiających się głównie w nieuchronnych uproszczeniach dokonywanych pomiarów, prezentowane odczyty pokazują pogarszanie się otoczenia regulacyjnego w dziedzinie prawa podatkowego. Wydaje się, że obecnie nie da się jeszcze udzielić odpowiedzi na pytanie, czy - przyjmując wzrost nakładów administracyjnych za nieuchronny koszt procesu „uszczelniania systemu podatkowego” - jest to koszt warty poniesienia w obliczu wzrostu dochodów podatkowych. Korzyści z procesu zwiększania wydajności fiskalnej systemu podatkowego są oczywiste i obserwowalne wyraźnie wcześniej niż koszty tego procesu. Co więcej, zmiany legislacyjne i organizacyjne sprawiają wrażenie dających niemal natychmiastowy efekt. Z dzisiejszej perspektywy pozytywne efekty przeważają nad innymi konsekwencjami prowadzonych działań. Zarówno obciążenia administracyjne, jak i brak realizacji założeń i celów legislacji wskazanych w ocenach skutków regulacji towarzyszących projektom legislacyjnym nie osiągnęły poziomu, którzy przyciągałbym uwagę nawet uczestników profesjonalnej dyskusji. Trzeba jednak zauważyć, że pomiar obciążeń administracyjnych jest nie tylko wolniejszy niż monitorowanie kasowych wpływów podatkowych. Abstrakcyjny charakter pojęcia kosztów administracyjnych wraz $\mathrm{z}$ ich charakterem następczym powodują zazwyczaj opóźnienie w pomiarze tego parametru, szczególnie w przypadku rankingów przygotowywanych przez instytucje zagraniczne. Wydaje się, że dla realnej oceny relacji koszt-efekt procesu uszczelniania systemu podatkowego wymagane będzie spojrzenie z perspektywy czasowej dłuższej niż obecnie.

102 https://www.heritage.org/index/country/poland (dostęp: 18.02.2020). 


\section{BiBLIOGRAFIA}

26 tys. podatników pod lupa skarbówki. Tak algorytm fiskusa wyłapuje podejrzane transakcje, https://gospodarka.dziennik.pl/podatki/artykuly/581817,podatki-podatnik-algorytm -skarbowka-fiskus-stir-wyludzenia.html (dostęp: 14.04.2019).

Analiza JPK_VAT i STIR gwarancja dalszego uszczelnienia systemu podatkowego, Ministerstwo Finansów, Warszawa, 3.10.2018.

CASE 2016, Study and Reports on the VAT Gap in the EU-28 Member States: 2016 Final Report; https://ec.europa.eu/taxation_customs/sites/taxation/files/2016-09_vatgap-report_final.pdf (dostęp: 26.02.2020).

CASE 2017, Study and Reports on the VAT Gap in the EU-28 Member States: 2017 Final Report, https://ec.europa.eu/taxation_customs/sites/taxation/files/study_and_re ports_on_the_vat_gap_2017.pdf (dostęp: 21.02.2020).

CASE 2018, Study and Reports on the VAT Gap in the EU-28 Member States: 2018 Final Report, https://ec.europa.eu/taxation_customs/sites/taxation/files/2018_vat_gap_ report_en.pdf (dostęp: 21.02.2020).

CASE. Ocena, czy poprzez wprowadzenie od dnia 1 października 2013 r. odwróconego obciążenia VAT na niektóre wyroby stalowe ograniczono nadużycia w rozliczaniu podat$k u$ VAT w obrocie tymi towarami oraz czy warunki funkcjonowania przedsiębiorstw w branży objętej zmianami uległy poprawie, Warszawa 2015.

Doing Business 2015-2019, International Bank for Reconstruction and Development / The World Bank, Washington 2015-2019.

Informacja o wynikach kontroli NIK, KBF.410.006.01.2019, Nr ewid. P/19/011, Warszawa 2020.

Informacja o wynikach kontroli NIK, KBF.410.007.00.2015, Nr ewid. 24/2016/P/15/011/KBF, Warszawa 2015.

Informacja o wynikach kontroli NIK, KBF.410.008.01.2016, Nr ewid. P/16/010, Warszawa 2017.

Informacja o wynikach kontroli NIK, KBF.430.002.2019, Nr ewid. 80/2019/P/18/011/ KBF, Warszawa 2019.

Informacja o wynikach kontroli NIK, KBF.430.003.2018, Nr ewid. 23/2018/P/17/013/ KBF, Warszawa 2018.

Informacja o wynikach kontroli NIK, KBF.430.012.2019, Nr ewid. 159/2019/P/18/009/ KBF, Warszawa 2019.

Informacja o wynikach kontroli NIK, LKR.430.005.2018, Nr ewid. 11/2019/P/18/077/ LKR, Warszawa 2019.

Koniec skażonego spirytusu na bazarach?, https://biznes.gazetaprawna.pl/artykuly/979 794,teraz-spirytus-w-pakiecie-skazony.html (dostęp: 14.04.2019).

Morawski I., Trzy lata rzadów PiS w polskiej gospodarce, Warszawa 2019.

Mudrecki A., Wykorzystanie mechanizmu odliczenia podatku naliczonego w systemie VAT do oszustw w postaci „,karuzeli podatkowych”, „Krytyka Prawa” 2018, t. 10, nr 3.

NIK ma zastrzeżenia do wdrażania JPK, „Dziennik Gazeta Prawna” 26.11.2018, https:// podatki.gazetaprawna.pl/artykuly/1365203,zastrzezenia-nik-do-mf-dot-wdrozenia -jpk.html (dostęp: 14.04.2019). 
Paying Taxes 2015-2019 PWC, The World Bank and International Finance Corporation, Washington 2015-2019.

Podsumowanie pierwszego miesiąca przesyłania JPK przez wszystkich czynnych podatników VAT, Ministerstwo Finansów, marzec 2018.

Radzikowski K., Mechanizm odwrotnego obciązenia - sanacja czy destrukcja podatku od towarów i usług?, „Doradztwo Podatkowe - Biuletyn Instytutu Studiów Podatkowych" 2018, nr 5.

Raport Szara Strefa rynku wyrobów tytoniowych, diagnoza, propozycje rozwiązań, Związek Przedsiębiorców i Pracodawców, Warszawa, grudzień 2018, www.zpp.net.pl (dostęp: 14.04.2019).

Sarnowski J., Selera P., Zmniejszenie luki VAT w Polsce w latach 2016-2017, przyczyny - środki - dalsze perspektywy, Warszawa 2018.

Study and Reports on the Vat Gap in the EU-28 Member States: 2017 Final Report. TAXUD/2015/CC/131, wrzesień 2017.

Ucieczka przed podatkami i kontrola podatkowa, red. H. Kuzińska, Warszawa 2018.

Walka z szara strefą. Wpływ regulacji na branżę paliw płynnych, Polska Organizacja Przemysłu i Handlu Naftowego, PWC, Warszawa 2018.

\section{“The TIGHTEN UP OF VAT SYSTEM" - AN ASSESSMENT ATTEMPT OF EFFECTIVENESS OF LEGISLATIVE AND ORGANIZATIONAL EFFORTS}

Summary. This paper essentially concentrates on legislative and administrative activities aimed to increase fiscal effectivity Value Added Tax. Main attention was focused on "anti-fraud efforts" implemented after year 2015. The main research question is as follows: whether the aim of "tightening up VAT system" was achieved and what was the cost. The cost "tightening up VAT system" was especially of additional tax burden - administrative cost levied on taxpayers. The purpose of the article is to take an attempt to answer to that question by the analysis of legislative and administrative measures and the cost/effect outcome of the measures implementation.

Keywords: VAT tax, closing tax gap, administrative costs 